\title{
Record of Decision Remedial Alternative Selection for the Fire Department Hose Training Facility (904-113G) Operable Unit
}

by

E. Palmer

Westinghouse Savannah River Company

Savannah River Site

Aiken, South Carolina 29808

DOE Contract No. DE-AC09-96SR18500

This paper was prepared in connection with work done under the above contract number with the U.S. Department of Energy. By acceptance of this paper, the publisher and/or recipient acknowledges the U.S. Government's right to retain a nonexclusive, royalty-free license in and to any copyright covering this paper, along with the right to reproduce and to authorize others to reproduce all or part of the copyrighted paper. 


\section{DISCLAIMER}

This report was prepared as an account of work sponsored by an agency of the United States Government. Neither the United States Government nor any agency thereof, nor any of their employees, makes any warranty, express or implied, or assumes any legal liability or responsibility for the accuracy, completeness, or usefulness of any information, apparatus, product, or process disclosed, or represents that its use would not infringe privately owned rights. Reference herein to any specific commercial product, process, or service by trade name, trademark, manufacturer, or otherwise does not necessarily constitute or imply its endorsement, recommendation, or favoring by the United States Government or any agency thereof. The views and opinions of authors expressed herein do not necessarily state or reflect those of the United States Government or any agency thereof.

This report has been reproduced directly from the best available copy.

Available to DOE and DOE contractors from the Office of Scientific and Technical Information, P. O. Box 62, Oak Ridge, TN 37831; prices available from (423) 576-8401.

Available to the public from the National Technical Information Service, U. S. Department of Commerce, 5285. Port Royal Road, Springfield, VA 22161. 


\section{DISCLAIMER}

Portions of this document may be illegible in electronic image products. Images are produced from the best available original document. 
United States Department of Energy

Savannah River Site

\section{Record of Decision}

Remedial Alternative Selection for the

Fire Department Hose Training Facility (904 -113G)

Operable Unit (U)

WSRC-RP-97-171

Revision 1

April 1998

Westinghouse Savannah River Company

Savannah River Site

Aiken, SC 29808

Prepared for the U. S. Department of Energy under Contract No. DE-AC09-96-SR18500

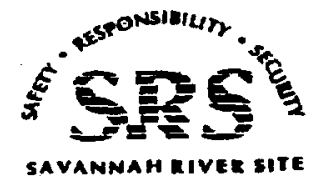


Printed in the United States of America

Prepared for

U.S. Department of Energy

and

Westinghouse Savannah River Company

Aiken, South Carolina 


\section{RECORD OF DECISION \\ REMEDIAL ALTERNATIVE SELECTION \\ FOR THE FIRE DEPARTMENT HOSE TRAINING FACILITY (904-113G) \\ OPERABLE UNIT (U)}

WSRC-RP-97-171

Revision 1

April 1998

Savannah River Site

Aiken, South Carolina

Prepared by:

Westinghouse Savannah River Company

for the

U. S. Department of Energy Under Contract DE-AC09-96SR1 8500

Savannah River Operations Office

Aiken, South Carolina 
This page intentionally left blank. 
Record of Decision for the Fire Department Hose Training Facility (904-113G)

Operable Unit (U)

Savannoh River Site, April 1998

DECLARATION FOR THE RECORD OF DECISION

\section{Unit Name and Location}

Fire Department Hose Training Facility (904-113G)

Savannah River Site

Aiken, South Carolina

The Fire Department Hose Training Facility (904-113G) (FDHTF) Operable Unit is listed as a Resource Conservation and Recovery Act (RCRA) 3004(u) solid waste management unit/Comprehensive Environmental Response, Compensation, and Liability Act (CERCLA) unit in Appendix $\mathrm{C}$ of the Federal Facility Agreement (FFA) for the Savannah River Site (SRS).

\section{Statement of Basis and Purpose}

This decision document presents the selected remedial alternative for the FDHTF located at the SRS in Aiken, South Carolina. The selected alternative was developed in accordance with RCRA, CERCLA, as amended, and to the extent practicable, the National Oil and Hazardous Substances Pollution Contingency Plan. This decision is based on the Administrative Record File for this specific RCRA/CERCLA unit.

\section{Description of the Selected Remedy}

The selected remedy for FDHTF is No Action. The previous soil removal activities conducted outside of CERCLA at the FDHTF have eliminated the need to perform additional remedial action. Other remedial alternatives for this unit were not considered because the Baseline Risk Assessment (BRA) showed that all of the constituents of concern (COCs) were eliminated because the risks indicated for the site were not attributed to activities performed at the FDHTF.

The risk levels developed in the BRA considered both the future residential and future industrial use scenarios. The uncertaint $y$ analysis performed in the BRA eliminated all human health and ecological COCs which meant that no remedial goal options (RGOs) were 
developed. There will be no post-Record of Decision documents since No Action is the preferred alternative for the FDHTF operable unit. The South Carolina Department of Health and Environmental Control has modified the SRS RCRA permit to incorporate No Action as the selected remedy.

\section{Declaration Statement}

Based on the FDHTF RCRA Facility Investigation/Remedial Investigation (RFI/RI) Report and the Baseline Risk Assessment, no action is necessary at the FDHTF to ensure the protection of human health and the environment. Since the FDHTF poses no risk to human health and the environment, and no action is needed, the CERCLA Section 121 requirements are not applicable. The selected remedy is protective of human health and the environment, complies with Federal and State requirements that are legally applicable or relevant and appropriate to the remedial action, and is meant to be a permanent solution, final action, for the FDHTF operable unit.

Section 300.430( $\mathrm{f}$ (ii) of the National Oil and Hazardous Substances Pollution Contingency Plan requires that Five-Year Review of Record of Decision be performed if hazardous substances, pollutants, or contaminants remain at the unit. The three Parties have determined that a Five-Year Review of Record of Decision for the FDHTF operable unit will not be performed. The remedial action for this unit (No Action) results in no hazardous substances, pollutants, or contaminants remaining in the soils of the FDHTF operable unit. 


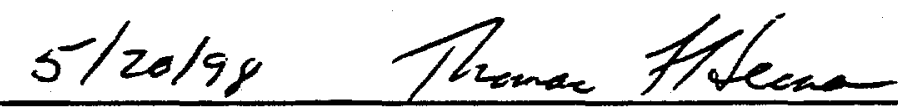

Date Thomas F. Heenan

Assistant Manager for Environmental Quality

U.S. Department of Energy, Savannah River Operations Office

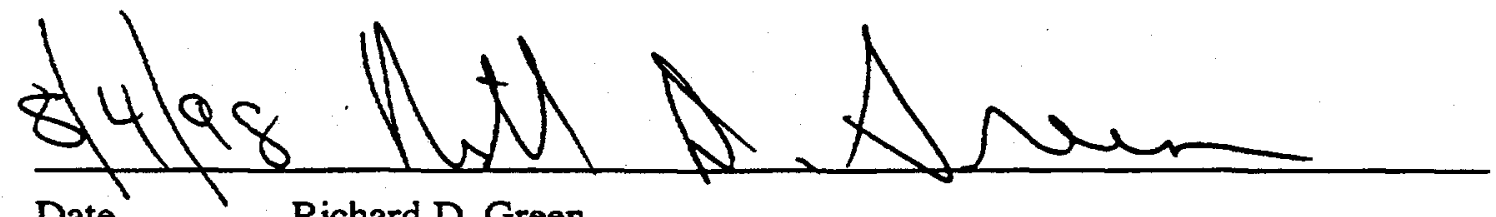

Date

Richard D. Green

Acting Division Director

Waste Management Division

U.S. Environmental Protection Agency - Region IV

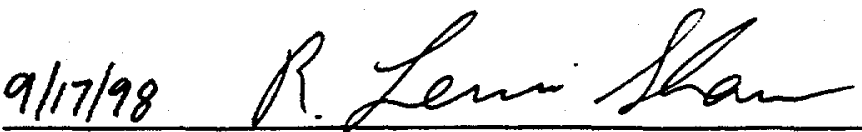

Date R. Lewis Shaw

Deputy Commissioner

Environmental Quality Control

South Carolina Department of Health and Environmental Control 
This page intentionally left blank. 


\title{
DECISION SUMMARY \\ REMEDIAL ALTERNATIVE SELECTION \\ FOR THE FIRE DEPARTMENT HOSE TRAINING FACILITY (904-113G) \\ OPERABLE UNIT (U)
}

\author{
WSRC-RP-97-171 \\ Revision 1 \\ April 1998
}

Savannah River Site

Aiken, South Carolina

Prepared by:

Westinghouse Savannah River Company

for the

U. S. Department of Energy Under Contract DE-AC09-96SR1 8500

Savannah River Operations Office

Aiken, South Carolina 


\section{TABLE OF CONTENTS}

Section

Declaration for the Record of Decision Declaration

I. Site and Operable Unit Name, Location, and Description

II. Operable Unit History and Compliance History

III.

Highlights of Community Participation.

IV.

Scope and Role of Operable Unit Within the Site Strategy .. ...8

V. Summary of Operable Unit Characteristics. .8

VI. Summary of Operable Unit Risks..

VII.

The Selected Remedy .40

VIII.

Explanation of Significant Changes.....

IX.

Responsiveness Summary. .. .42

$\mathrm{X}$.

References. .. .42

\section{LIST OF FIGURES}

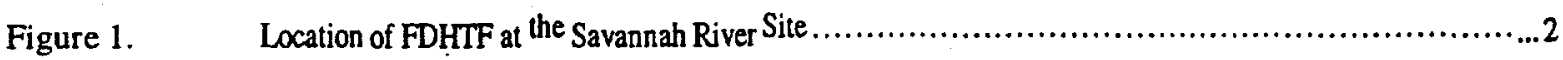

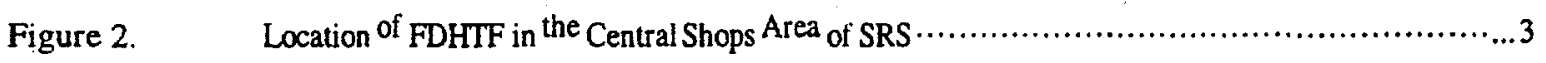

Figure 3. Location of FDHTF in the Fourmile Branch Watershed .........................................

Figure 4. Soil Sample Locations, Monitoring Well Locations, and the Estimated

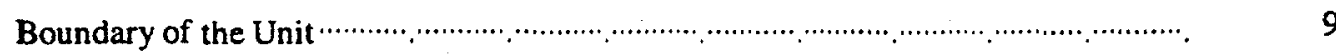

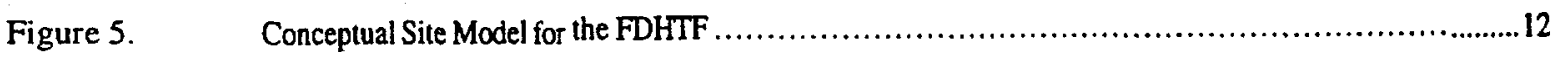

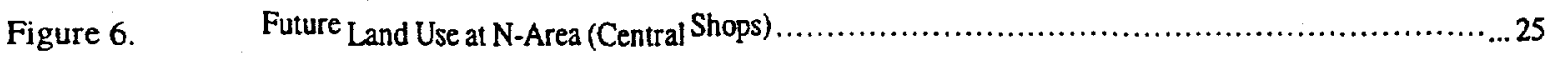

Figure 7. Summary of Chemical Risks and Hazards Across Pathways and Receptors

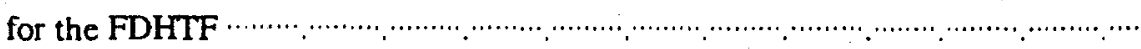




\section{LIST OF TABLES}

Table 1. Unit Specific Background Soil Concentrations at the Fire Department Hose Training Facility

Table 1. Unit Specific Background Soil Concentrations at the Fire Department Hose Training Facility (Continued). 14

Table 2. Summary Statistics for Analytes Detected in Soil Samples from 0 to $1 \mathrm{ft}$ Deep from the Fire Department Hose Training Facility .

Table 2. Summary Statistics for Analytes Detected in Soil Samples from 0 to $1 \mathrm{ft}$ Deep from the Fire Department Hose Training Facility (Continued)

Table 3. Summary Statistics for Analytes Detected in Soil Samples from 0 to $4 \mathrm{ft}$ Deep from the Fire Department Hose Training Facility.

Table 3. Summary Statistics for Analytes Detected in Soil Samples from 0 to $4 \mathrm{ft}$

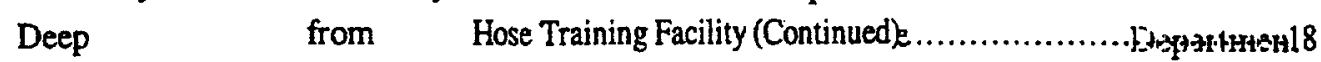

Table 4. Summary Statistics for Analytes Detected in Soil Samples from $>4 \mathrm{ft}$ Deep from the Fire Department Hose Training Facility...

Table 4. Summary Statistics for Analytes Detected in Soil Samples from $>4 \mathrm{ft}$ Deep from the Fire Department Hose Training Facility (Continued).

Table 5 . RME Risk Characterization Summary: FDHTF Surface Soil ( 0 to $]$ foot)

Table 6.

RME Risk Characterization Summary: FDHTF Subsurface Soil (0 to 4 foot)

Table 7. RME Risk Characterization Summary: FDHTF Background Surface Soil (0 to 1 foot)

Table 8. RME Risk Characterization Summary: FDHTF Background Subsurface Soil (0 to 4 foot) .30

Table 9. Health-Based COCs for Soil and Produce Fire Department Hose Training Facility 31

Table 10. Summary Statistics for Soil Background Concentrations from 0 to $1 \mathrm{ft}$ in the FDHTF.

Table 11. Summary Statistics for Soil Background Concentrations from 0 to $4 \mathrm{ft}$ in the FDHTF. 


\section{Acronyms}

BRA Baseline Risk Assessment

CERCLA Comprehensive Environmental Response, Compensation, and Liability Act

$\mathrm{COC}$ Constituent of Concern

COPC Constituent of Potential Concern

DOE

U.S. Department of Energy

ELCR

Excess Lifetime Cancer Risk

EPA

Environmental Protection Agency

FDHTF Fire Department Hose Training Facility (940-113G)

FFA Federal Facility Agreement

HI Hazard Index

HQ Hazard Quotient

PCB Polychlorinated Biphenyl

RCRA Resource Conservation and Recovery Act

RfD Reference Dose

RFI/RI RCRA Facility Investigation/Remedial Investigation

RGO Remedial Goal Option

RME Reasonable Maximum Exposure

ROD Record of Decision

SCDHEC South Carolina Department of Health and Environmental Control

SCHWMR South Carolina Hazardous Waste Management Regulations

SRS Savannah River Site

SVOC Semi-Volatile Organic Compounds

SWMU Solid Waste Management Unit

TPH Total recoverable Petroleum Hydrocarbon

USC Unit Specific Constituents

VOC Volatile Organic Compound

WSRC Westinghouse Savannah River Company 
This page intentionally left blank. 


\section{SITE AND OPERABLE UNIT NAME, LOCATION, AND DESCRIPTION}

Savannah River Site (SRS) occupies approximately 800 square kilometers (310 square miles) of land adjacent to the Savannah River, principally in Aiken and Barnwell counties of South Carolina. SRS is a secured U.S. Government facility with no permanent residents. SRS is located approximately 40 kilometers (25 miles) southeast of Augusta, Georgia, and 32 kilometers (20 miles) south of Aiken, South Carolina.

SRS is owned by the U.S. Department of Energy (DOE). Management and operating services are provided by Westinghouse Savannah River Company (WSRC). SRS has historically produced tritium, plutonium, and other special nuclear materials for national defense.

The Fire Department Hose Training Facility (940-113G) (FDHTF) is located approximately $200 \mathrm{~m} \mathrm{(700} \mathrm{ft)} \mathrm{northeast} \mathrm{of} \mathrm{the} \mathrm{intersection} \mathrm{of} \mathrm{Roads} \mathrm{C} \mathrm{and} 6$ and approximately $6 \mathrm{~m}(20 \mathrm{ft})$ west and downgradient of a heat exchanger storage pad (Laydown Area, 745-N) (Figures 1 and 2). The FDHTF is a source control and groundwater operable unit which is included in the Fourmile Branch watershed (Figure 3). The FFA lists FDHTF as a RCRAVCERCLA unit, requiring evaluation using an investigation/assessment process that integrates and combines the RFI process with the CERCLA Remedial Investigation (RI) to determine the actual or potential impact to human health and the environment.

\section{OPERABLE UNIT HISTORY AND COMPLIANCE HISTORY}

\section{Operable Unit History}

The FDHTF was built between 1975 and March 1979 and operated by the SRS Fire Department between 1979 and 1982 to train personnel in fighting waste oil fires. The training facility consisted of an approximately 6 by $12 \mathrm{~m}$ ( 20 by $40 \mathrm{ft}$ ) unlined shallow pit surrounded by an approximately $0.5 \mathrm{~m}(1.5 \mathrm{ft})$ high asphalt dike. Training exercises typically included pouring burnable oil into the unit, igniting the oil, and then having the fire department extinguish the fire with water from fire hydrants located adjacent to the unit. No known hazardous wastes were placed in the unit. 
Figure 1. Location of FDHTF at the Savannah River Site

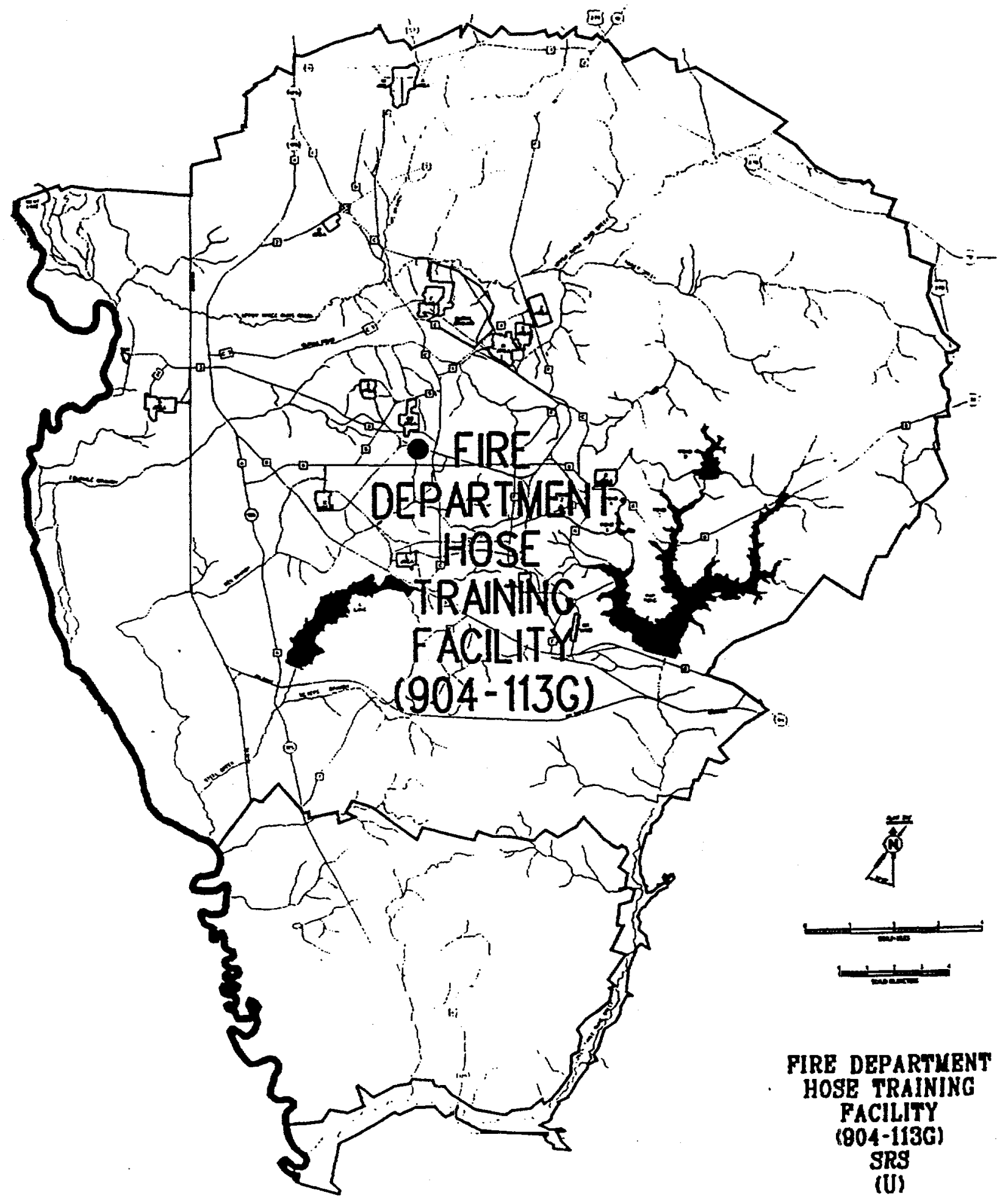


Record of Decision for the Fire Department Hose Training Facility (904-113G)

Figure 2. Location of FDHTF in the Central Shops Area of SRS
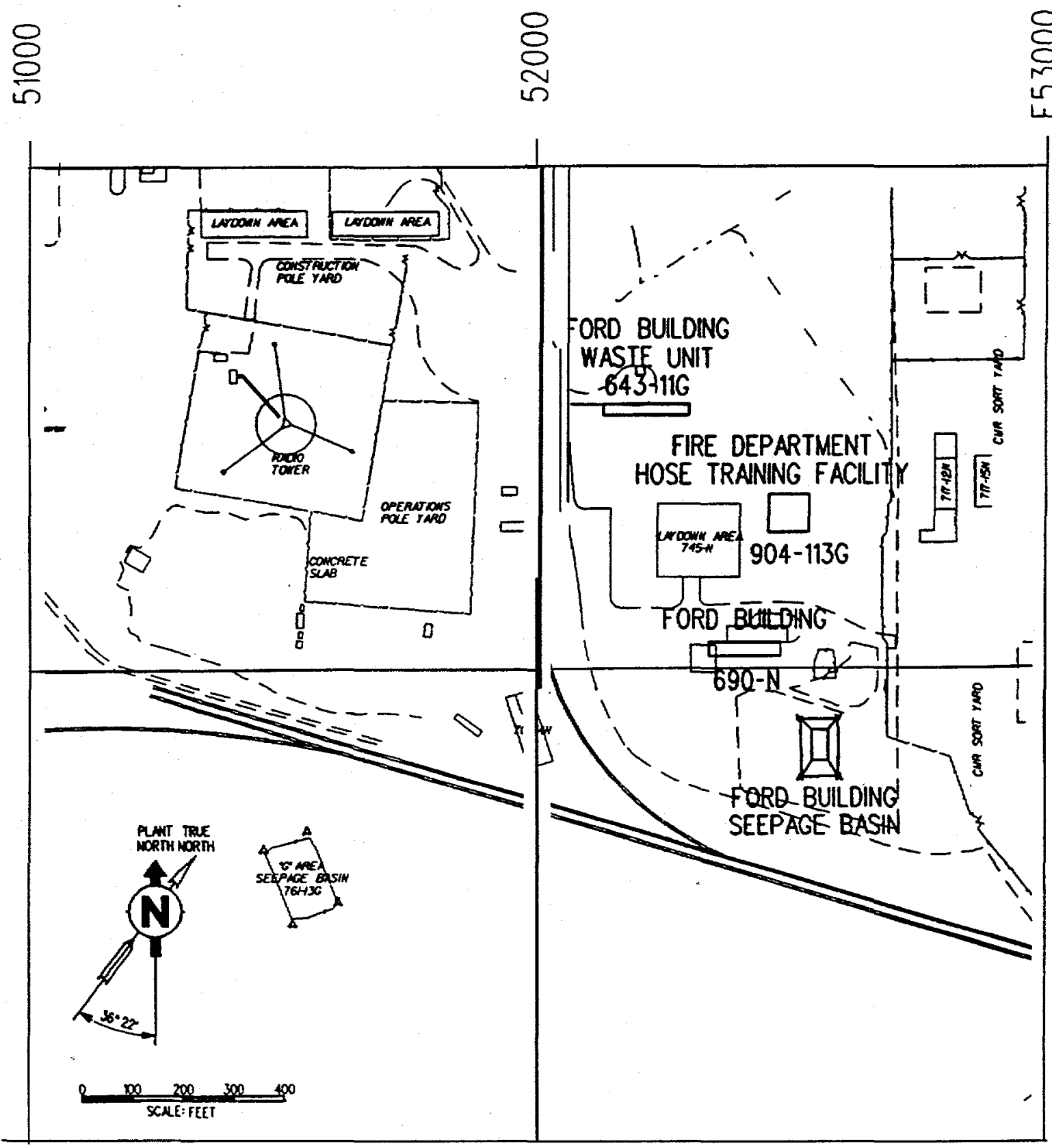
Figure 3. Location of FDHTF in the Fourmile Branch Watershed

Figure 3. Location of knthrin the Tourmile Branch Watershed

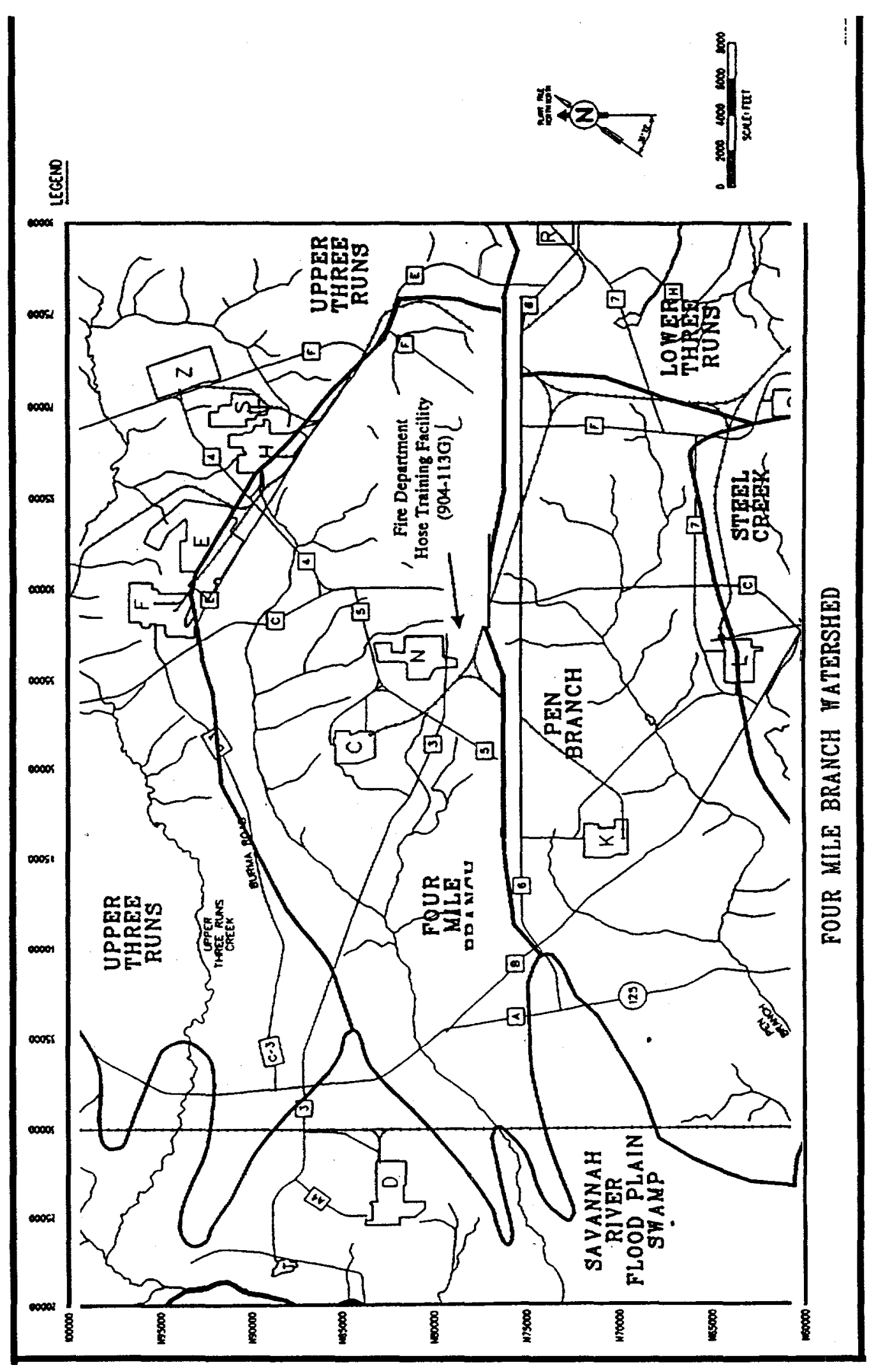


The SRS Fire Department discontinued use of the FDHTF and recommended the facility for cleanup and closure in March 1982. Available documentation indicates cleanup activities occurred on November 21,1982 during which 14 loads of oil-contaminated soil were excavated from an area approximately 6 by 6 by $1 \mathrm{~m}$ ( 20 by 20 by $3 \mathrm{ft}$ ) and transported to the sanitary landfill. The date of this cleanup activity could not be verified, however, an aerial photograph from 1983 shows the FDHTF still present. An additional aerial photograph from June 1984 shows the FDHTF pit had been removed and the area excavated. The excavated area is approximately 10 to $12 \mathrm{~m}$ ( 30 to $40 \mathrm{ft}$ ) wide by 15 to $18 \mathrm{~m}$ (50 to $60 \mathrm{ft}$ ) long and the pit dikes and visible contaminated soils are removed. An additional area 3 to $5 \mathrm{~m}$ (10 to $15 \mathrm{ft}$ ) wide by 10 to $12 \mathrm{~m}$ ( 30 to $40 \mathrm{ft}$ ) long, visible on the north side of the main excavation, is either an additional remediated area, a pile of the excavated material, or material intended for backfill. The photographs indicate that either existing documentation is incorrect $(11 / 21 / 82$ is actually $11 / 21 / 83$ ) or that a more extensive excavation took place between July 1983 and June 1984. Subsequent inspections during 1985 indicated that an additional area approximately $1 \mathrm{~m}$ by $1 \mathrm{~m}$ ( 3 by $3 \mathrm{ft}$ ), of visibly contaminated soil was placed here from an unknown source. This area was also excavated to a depth of approximately $0.6 \mathrm{~m}(2 \mathrm{ft})$ and the soil removed from the site in a manner similar to the 1982/84 cleanup activities.

\section{SRS Compliance History}

At SRS, waste materials regulated under RCRA are managed in accordance with the requirements of RCRA. Certain SRS activities have required treatment, storage, disposal or post-closure permits under RCRA. Non-regulated units, called solid waste management units (SWMU), include any activity where hazardous constituents may remain uncontrolled and may potentially release to the environment. Investigation and potential corrective action for these SWMU(s) are mandated under RCRA 3004(u). On September 5, 1995, SRS received a hazardous waste permit from SCDHEC which includes corrective action requirements. Specifically, part V of the permit mandates that SRS establish and implement a RCRA Facility Investigation (RFI) Program to fulfill the requirements specified in Section 3004(u) of RCRA.

Hazardous substance, as defined by CERCLA, are also present in the environment at the SRS. On December 21, 1989, SRS was included on the National Priorities List. This inclusion created a need to integrate the established RFI Program with CERCLA requirements to 
provide for a focused environmental program. In accordance with Section 120 of CERCLA, DOE has negotiated a Federal Facility Agreement (FFA, 1993) with the EPA and SCDHEC to coordinate remedial activities at SRS into one comprehensive strategy which fulfills these dual regulatory requirements.

The RFI/RI/BRA for the Fire Department Hose Training Facility (904-113G) was completed in 1997. The results of this report indicate that there is no impact (or potential impact) to human health or the environment from the FDHTF. The previous soil removal activities at the FDHTF have eliminated the need to perform additional remedial action. Therefore, No Action is warranted. No other alternatives were considered.

According to EPA guidance, if there is no current or potential threat to human health and the environment and No Action is warranted, the CERCLA 121 requirements are not triggered. This means that there is no need to evaluate other alternatives or the No Action alternative against the nine criteria specified under CERCLA.

The remedy selected satisfies both the CERCLA and RCRA 3004(u) requirements. The SCDHEC has modified the SRS RCRA permit to incorporate the selected remedy.

\section{HIGHLIGHTS OF COMMUNITY PARTICIPATION}

Both RCRA and CERCLA require that the public be given an opportunity to review and comment on the draft permit modification and proposed remedial alternative. Public participation requirements are listed in South Carolina Hazardous Waste Management Regulation (SCHWMR) R.61-79. 124 and Sections 113 and 117 of CERCLA. These requirements include establishment of an Administrative Record File that documents the investigation and selection of the remedial alternatives for addressing the FDHTF soils and groundwater. The Administrative Record File must be established at or near the facility at issue. The SRS Public Involvement Plan (DOE, 1994) is designed to facilitate public involvement in the decision-making process for permitting, closure, and the selection of remedial alternatives. The SRS Public Involvement Plan addresses the requirements of RCRA, CERCLA, and the National Environmental Policy Act. SCHWMR R.61 -79.124 and Section 117(a) of CERCLA, as amended, required the advertisement of the draft permit modification and notice of any proposed remedial action and provided the public an 
opportunity to participate in the selection of the remedial action. The Statement of Basis/Proposed Plan for the Fire Department Hose Training Facility (940-1 13G) (WSRC, 1997b), which is part of the Administrative Record File, highlights key aspects of the investigation and identifies the preferred action for addressing the FDHTF.

The FFA Administrative Record File, which contains the information pertaining to the selection of the response action, is available at the EPA office and at the following locations:

U. S. Department of Energy

Public Reading Room

Gregg-Graniteville Library

University of South Carolina-Aiken

171 University Parkway

Aiken, South Carolina 29801

(803) 641-3465

Thomas Cooper Library

Government Documents Department

University of South Carolina

Columbia, South Carolina 29208

(803) 777-4866
Asa H. Gordon Library

Savannah State University

Tompkins Road

Savannah, Georgia 31404

(912) 356-2183 


\section{SCOPE AND ROLE OF OPERABLE UNIT WITHIN THE SITE STRATEGY}

The overall strategy for addressing the FDHTF was to: (1) characterize the waste unit by delineating the nature and extent of contamination and identifying the media of concern (perform the RFI/RI); (2) perform a baseline risk assessment to evaluate media of concern, COCs, exposure pathways, and characterize potential risks; and (3) evaluate and perform a final action to remediate, as needed, the identified media of concern.

The FDHTF is a source control and groundwater operable unit which is included in the Fourmile Branch watershed. There are no surface waters present near the unit, but a small wet weather conveyance northwest of the unit runs in a northerly direction. An unnamed tributary of Fourmile Branch is located approximately $460 \mathrm{~m}(1,500 \mathrm{ft})$ to the north, northeast of the FDHTF.

The SRS has recently concluded a surface and subsurface soil investigation at the FDHTF. Based upon preliminary characterization results, SCDHEC and EPA concurred with DOE's proposal to separate the operable unit into two operable units (i.e., the Ford Building Waste Site and the Fire Department Hose Training Facility). SCDHEC and EPA also agreed that the investigation at the FDHTF adequately characterized contamination within that unit and along potential migration pathways. This ROD will propose a final remedial action for the operable unit at the FDHTF.

\section{SUMMARY OF OPERABLE UNIT CHARACTERISTICS}

\section{Media Assessment}

The soil and groundwater sampling activities conducted in 1996 at the FDHTF and background locations (Figure 4) provided data on the types and extent of constituents present and supplemented soil gas surveys conducted in 1986 and 1992. The primary source of contamination at the FDHTF would be the soil impacted by oils and associated fuels burned at the facility. This soil was removed during 1982/84 cleanup activities. 
Figure 4. Soil Sample Locations, Monitoring Well Locations, and the Estimated Boundary of the Unit

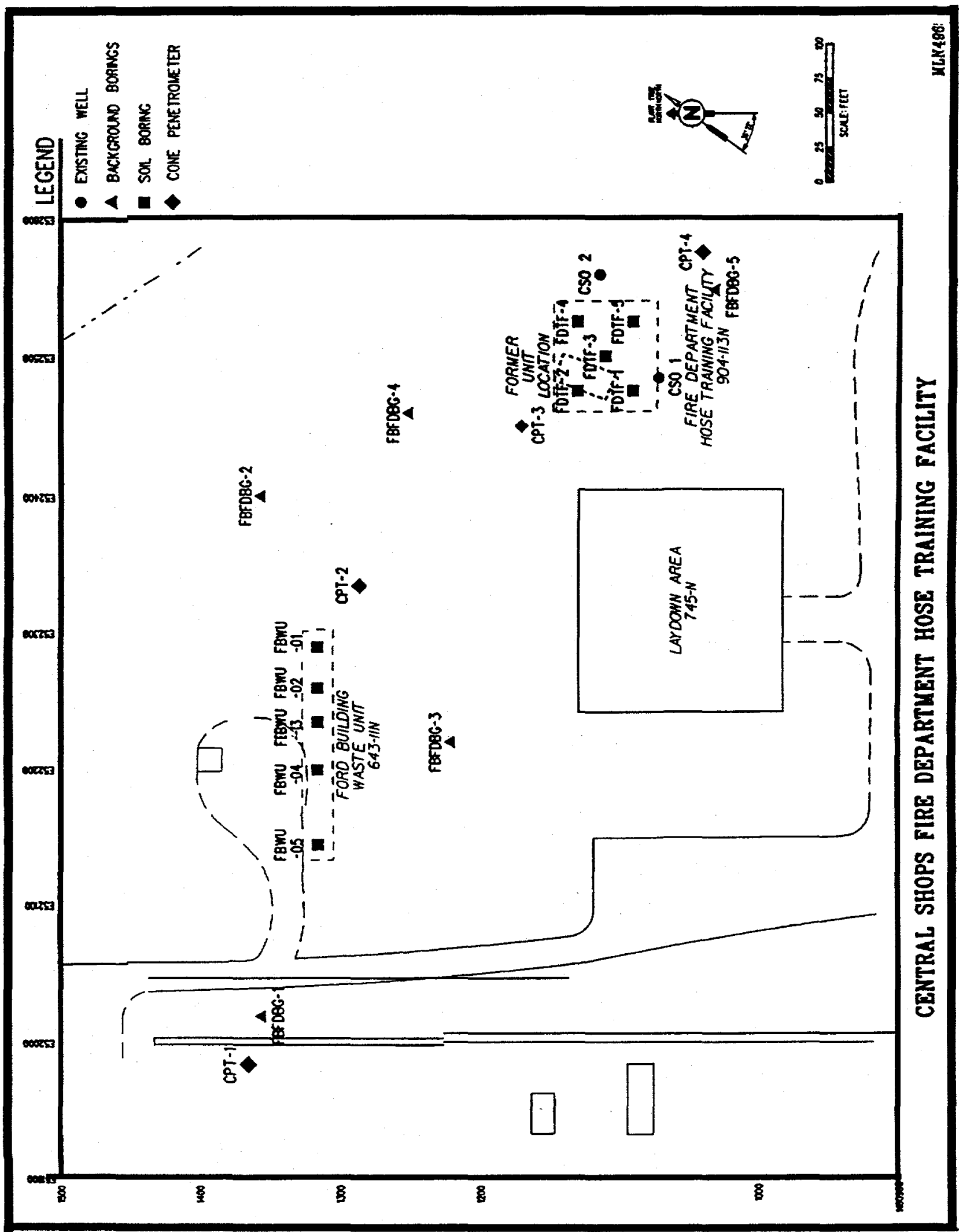


A Conceptual Site Model was prepared which shows the potential human health and ecological receptors and exposure pathways to assist in determining what samples were needed during characterization. This Conceptual Site Model is shown in Figure 5.

During the 1996 site characterization the surface soil was sampled from 0 to $0.3 \mathrm{~m}$ ( 0 to $1 \mathrm{ft}$ ) and subsurface soil in the interval from 0 to $1.2 \mathrm{~m}(0$ to $4 \mathrm{ft})$ at 5 locations in the FDHTF. Samples received analysis for a full analytical suite: metals/inorganics, volatile organic compounds (VOCs), semi-volatile organic compounds (SVOCs), and pesticides/ polychlorinated biphenyls (PCBs)/dioxins and furans. Past records and activities did not indication that radionuclides had ever been disposed of at the FDHTF, so samples were only tested for radionuclide indicators and were not speciated. Manganese and two SVOCs, benzo(a)pyrene and benzo(g,h,i)perylene, were identified as unit specific constituents (USCs) in the surface soil (0-1 ft). No VOCs, pesticides, PCBs, dioxins, furans or radionuclides were identified as USCs for surface soils (0-1').

Eight metals were identified as USCs in the subsurface soil $(0-4 \mathrm{ft})$ : aluminum, arsenic, beryllium, chromium, iron, manganese, sodium, and vanadium. Two SVOCs, benzo(a)pyrene and benzo(g,h,i)pery lene, were identified as USCs in the subsurface soil. The SVOCs were not detected deeper than $0.3 \mathrm{~m}$ ( $1.0 \mathrm{ft})$. No VOCs, pesticides, PCBs, dioxins, furans or radionuclides were identified as USCs for subsurface soils.

Seven metals were identified as USCs in the deep soil (1.2 to $4.0 \mathrm{~m}$ [4 to $13 \mathrm{ft}]$ ): aluminum, arsenic, beryllium, chromium, iron, sodium, and vanadium. No VOCs, SVOCs, pesticides, PCBs, dioxins, furans or radionuclides were identified as USCs for the deep soils at FDHTF. Tables 1 through 4 summarize the contaminants found in the background, $0-1 \mathrm{ft}$ deep, $0-4 \mathrm{ft}$ deep, and $>4 \mathrm{ft}$ deep soil samples.

The historical groundwater monitoring data has resulted in an analytical suite refined to aluminum and total recoverable petroleum hydrocarbons (TPH). No TPHs have been detected during the periodic monitoring program, so groundwater sampling was not conducted in the 1996 investigation.

The groundwater migration pathway evaluation determined that no constituents are present in the soil in quantities sufficient to migrate through the soil to cause concentrations above acceptable 
levels. Previous groundwater monitoring data do not indicate that the groundwater has been impacted by the FDHTF or any other source of contaminants. The constituents present in the soil of the FDHTF at concentrations above two times their average background concentration were screened against EPA generic soil screening levels using a dilution attenuation factor (DAF) of 20 to identify those which would require vadose zone transport modeling. The use of the generic DAF of 20 is based on the unit source being less than 0.5 acres and the fact that the groundwater is not near the surface (i.e., depth to groundwater is approximately 50 feet). No constituent is present in the FDHTF soil at an average concentration exceeding its generic screening level with a DAF of 20.

The results of the FDHTF characterization study are summarized in Tables 1 through 4 . Table 1 lists the data for the background soil samples. Tables 2 through 4 contain the data for the 0 to $1 \mathrm{ft}, 0$ to $4 \mathrm{ft}$, and greater than $4 \mathrm{ft}$ deep soil intervals, respectively. 
Figure 5. Conceptual Site Model for the FDHTF
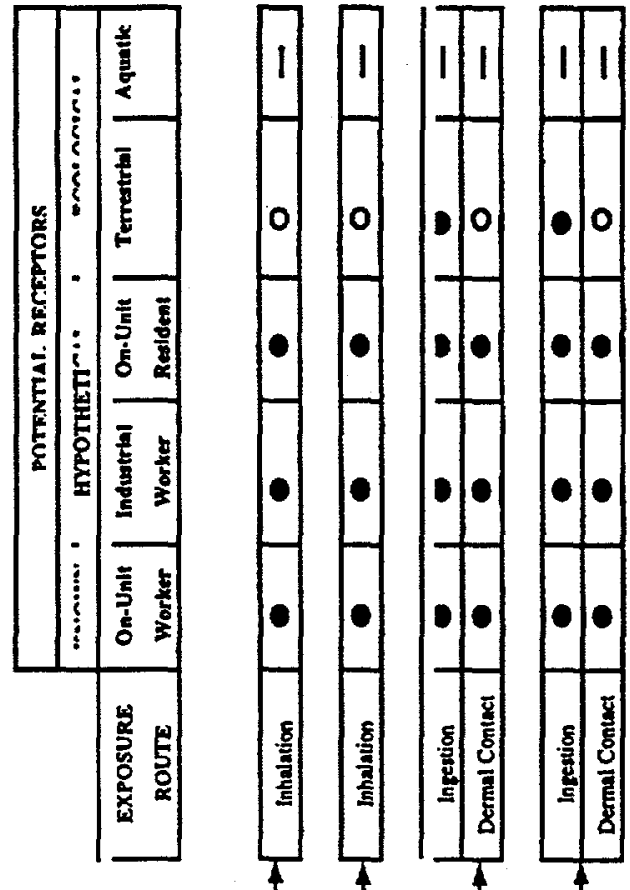

|ٕ.

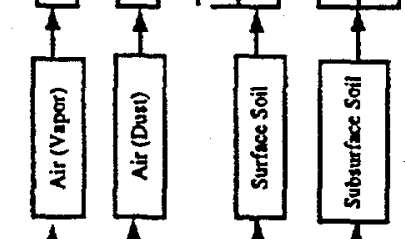

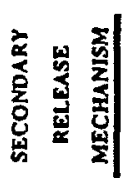
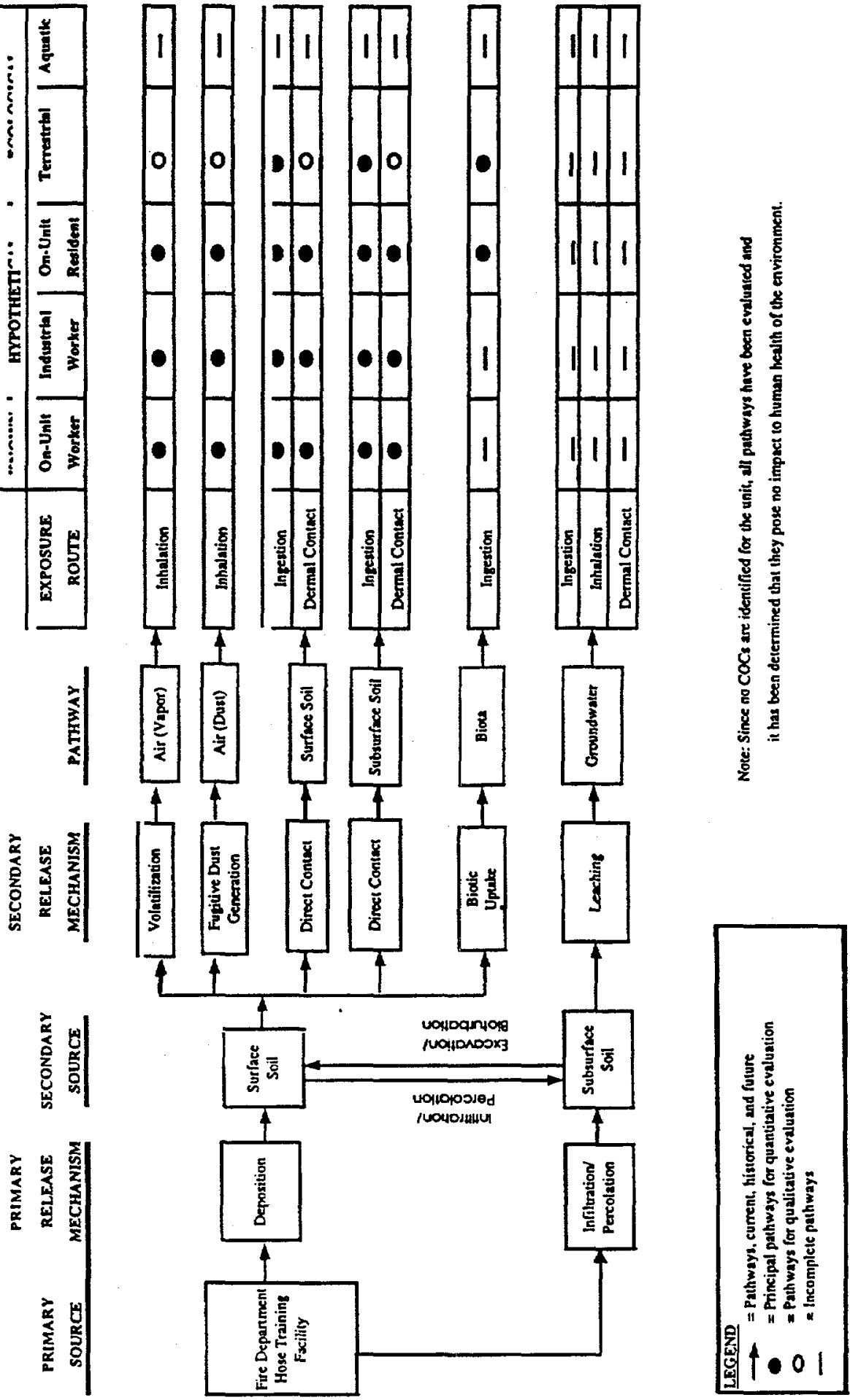
Table 1. Unit Specific Background Soil Concentrations at the Fire Department Hose Training Facility

\begin{tabular}{|c|c|c|c|c|c|c|}
\hline Analyte (Units) & $\begin{array}{c}\text { Surface Bkgd } \\
(0-1 \mathrm{ft})\end{array}$ & $\begin{array}{c}2 \mathrm{X} \\
\text { Surface } \\
\text { Bkgd }\end{array}$ & $\begin{array}{c}\text { Subsurface Bikgd } \\
(0-4 \mathrm{ft})\end{array}$ & $\begin{array}{c}2 \mathrm{X} \text { Subsurface } \\
\text { Bkgd }\end{array}$ & $\begin{array}{c}\text { Deep Soil } \\
\text { Bkgd } \\
\text { (>4 ft) }\end{array}$ & $\begin{array}{c}2 \mathrm{X} \\
\text { Deep Bkgd }\end{array}$ \\
\hline \multicolumn{7}{|l|}{$\begin{array}{l}\text { Metals/Inorganics } \\
(\mathrm{mg} / \mathrm{kg})\end{array}$} \\
\hline Aluminum & 6300 & 12600 & 5890 & 11800 & 4700 & 9400 \\
\hline Antimony & 0.663 & 1.33 & 0.579 & 1.16 & 0.801 & 1.6 \\
\hline Arsenic & 3.26 & 6.52 & 2.87 & 5.74 & 3.52 & 7.04 \\
\hline Barium & 12.9 & 25.8 & 13.3 & 26.6 & 5.73 & 11.5 \\
\hline Beryllium & 0.103 & 0.206 & 0.0972 & 0.194 & 0.0754 & 0.151 \\
\hline Cadmium & 0.27 & 0.54 & 0.307 & 0.614 & 0.64 & 1.28 \\
\hline Calcium & 155 & 310 & 152 & 304 & 88.4 & 177 \\
\hline Chromium & 14.2 & 28.4 & 12.5 & 25 & 15.9 & 31.8 \\
\hline Cobalt & 0.512 & 1.02 & 0.49 & 0.98 & 0.232 & 0.464 \\
\hline Copper & 11.2 & 22.4 & 6.95 & 13.9 & 4.15 & 8.3 \\
\hline Cyanide & 0.16 & 0.32 & 0.183 & 0.366 & 0.181 & 0.362 \\
\hline Iron & 11200 & 22400 & 10500 & 21000 & 18200 & 36400 \\
\hline Lead & 7.68 & 15.4 & 6.04 & 12.1 & 6.38 & 12.8 \\
\hline Magnesium & 78.7 & 157 & 79.4 & 159 & 74.3 & 149 \\
\hline Manganese & 21.7 & 43.4 & 19.7 & 39.4 & 2.42 & 4.84 \\
\hline Mercury & 0.0435 & 0.087 & 0.0412 & 0.0824 & 0.035 & 0.07 \\
\hline Nickel & 1.94 & 3.88 & 1.66 & 3.32 & 0.844 & 1.69 \\
\hline Potassium & 71 & 142 & 69.1 & 138 & 48.1 & 96.2 \\
\hline Selenium & ND & ND & 0.489 & 0.978 & 1.74 & 3.48 \\
\hline Sodium & 35.2 & 70.4 & 29.8 & 59.6 & 29.9 & 59.8 \\
\hline Vanadium & 30.4 & 60.8 & 27.2 & 54.4 & 67.7 & 135 \\
\hline Zinc & 6.28 & 12.6 & 4.52 & 9.04 & 2.17 & 4.34 \\
\hline \multicolumn{7}{|l|}{ SVOCs ( $\mu \mathrm{g} / \mathrm{kg})$} \\
\hline Di-n-octyl phthalate & ND & ND & ND & ND & 229 & 458 \\
\hline Phenol & ND & ND & ND & ND & 44.9 & 89.8 \\
\hline
\end{tabular}

* The background concentration is the mean of all results above the detection limit for samples from stations FBFDB01, FBFDB-02, FBFDB-03, FDFDB-04 and FBFDB-05. "ND" indicates that the analyte was not detected in any background samples in that depth interval. 
Record of Decision for the Fire Department Hose Training Facility (904-1 13G)

Operable, Unit (U)

WSRC-RP-97-171

Sarannah River Site, April 1998

Revision 1

Page 14 of 42

Table 1. Unit Specific Background Soil Concentrations at the Fire Department Hose Training Facility (Continued)

\begin{tabular}{|c|c|c|c|c|c|c|}
\hline Analyte (Units) & $\begin{array}{l}\text { Surface Blgd } \\
\quad(0-1 \mathrm{ft})\end{array}$ & $\begin{array}{c}2 X \\
\text { Surface Bkgd }\end{array}$ & $\begin{array}{c}\text { Subsurface } \\
\text { Bkgd } \\
(0-4 \mathrm{ft}) \\
\end{array}$ & $\begin{array}{c}2 X \\
\text { Subsurface } \\
\text { Bkgd } \\
\end{array}$ & $\begin{array}{l}\text { Deep } \\
\text { Blogd } \\
(>4 \mathrm{ft})\end{array}$ & $\begin{array}{c}2 X \\
\text { Deep Bkgd }\end{array}$ \\
\hline \multicolumn{7}{|l|}{ Radionuclides ( $\mathrm{pCi} / \mathrm{g}$ ) } \\
\hline Actinium-228 & 1.07 & 2.14 & 1.14 & 2.28 & 1.28 & 2.56 \\
\hline Americium-241 & 0.865 & 1.73 & 0.795 & 1.59 & 0.842 & 1.68 \\
\hline Antimony-124 & 0.06 & 0.12 & 0.06 & 0.12 & ND & ND \\
\hline Antimony-1 25 & ND & ND & ND & ND & 0.15 & 0.3 \\
\hline Barium-133 & ND & ND & ND & ND & 0.07 & 0.14 \\
\hline Cesium-134 & ND & ND & ND & ND & 0.06 & 0.12 \\
\hline Cesium-137 & 0.175 & 0.35 & 0.175 & 0.35 & ND & ND \\
\hline Cobalt -60 & ND & ND & 0.06 & 0.12 & ND & ND \\
\hline Europium-152 & 0.33 & 0.66 & 0.34 & 0.68 & 0.302 & 0.604 \\
\hline Europium-155 & 0.263 & 0.526 & 0.377 & 0.754 & 0.253 & 0.506 \\
\hline Gross Alpha & 14.7 & 29.4 & 16.7 & 33.4 & 18.1 & 36.2 \\
\hline Iodine-129 & 5.05 & 10.1 & 5.05 & 10.1 & ND & ND \\
\hline Lead-212 & 1.47 & 2.94 & 1.48 & 2.96 & 1.55 & 3.1 \\
\hline Manganese-54 & ND & ND & ND & ND & 0.06 & 0.12 \\
\hline Neptunium-239 & ND & ND & ND & ND & 0.87 & 1.74 \\
\hline Non-volatile Beta & 14.6 & 29.2 & 13.7 & 27.4 & 16.9 & 33.8 \\
\hline Plutonium-238 & 0.32 & 0.64 & 0.23 & 0.46 & 0.295 & 0.59 \\
\hline Potassium-40 & 1.16 & 2.32 & 1.26 & 2.52 & 1.65 & 3.3 \\
\hline Promethium-146 & ND & ND & $\mathrm{ND}$ & ND & 0.05 & 0.1 \\
\hline Promethium-147 & ND & ND & ND & ND & 1.12 & 2.24 \\
\hline Radium-226 & 0.22 & 0.44 & 0.273 & 0.546 & 0.257 & 0.514 \\
\hline Radium-228 & 1.69 & 3.38 & 1.36 & 2.72 & 2.83 & 5.66 \\
\hline Ruthenium-106 & ND & ND & ND & ND & 2.1 & 4.2 \\
\hline Strontium-90 & ND & ND & 0.47 & 0.94 & 0.78 & 1.56 \\
\hline Technetium-99 & 0.215 & 0.43 & 0.148 & 0.296 & 0.176 & 0.352 \\
\hline Thorium-228 & 1.44 & 2.88 & 1.37 & 2.74 & 1.56 & 3.12 \\
\hline Thorium-232 & 0.967 & 1.93 & 1.08 & 2.16 & 1.45 & 2.9 \\
\hline Thorium-234 & 1.49 & 2.98 & 1.35 & 2.7 & 1.63 & 3.26 \\
\hline Tin-113 & ND & ND & ND & $\mathrm{ND}$ & 0.08 & 0.16 \\
\hline Uranium-235 & ND & ND & 0.13 & 0.26 & 0.14 & 0.28 \\
\hline Yttrium-88 & ND & ND & 0.05 & 0.1 & ND & ND \\
\hline Zinc-65 & ND & ND & ND & ND & 0.08 & 0.16 \\
\hline
\end{tabular}

* The background concentration is the mean of all results above the detection limit for samples from stations FBFDB01. FBFDB-02, FBFDB-03, FDFDB-04 and FBFDB-05. "ND" indicates that the anal yte was not detected in any background samples in that depth interval. 
Table 2. Summary Statistics for Analytes Detected in Soil Samples from $\mathbf{0}$ to $1 \mathrm{ft}$ Deep from the Fire Department Hose Training Facility

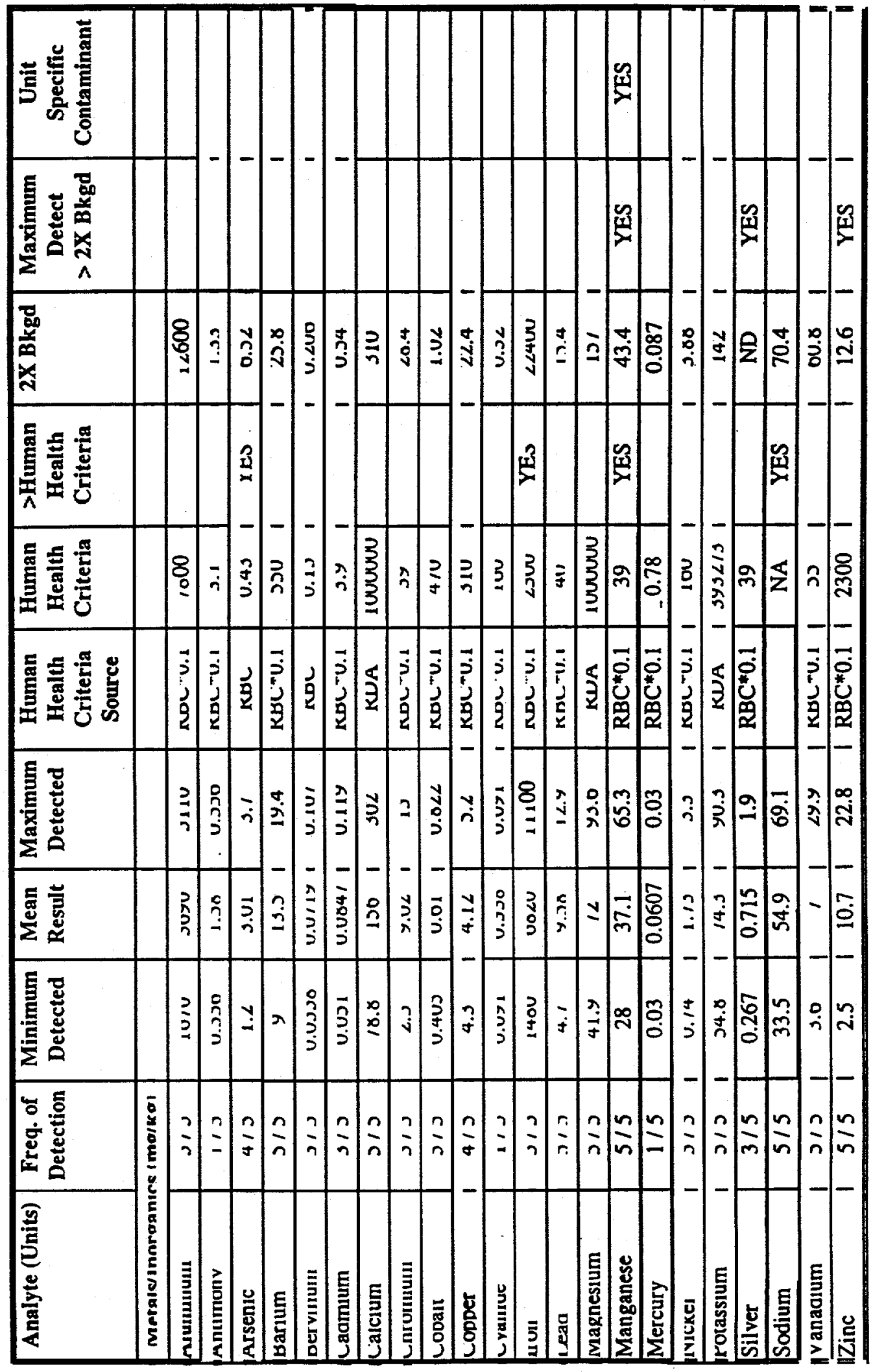


Table 2. Summary Statistics for Analytes Detected in Soil Samples from 0 to $1 \mathrm{ft}$ Deep from the Fire Department Hose Training Facility (Continued)

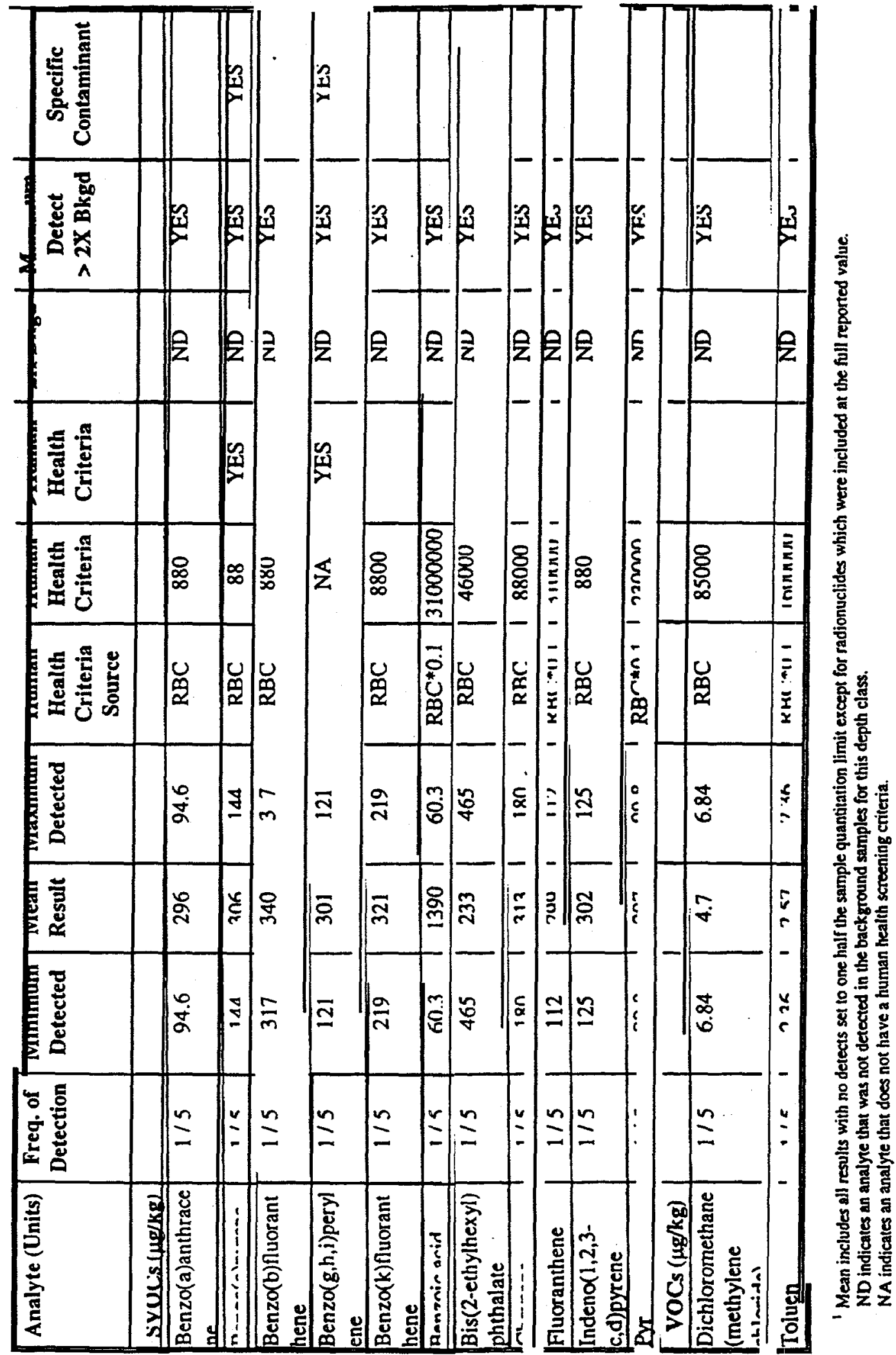


Table 3. Summary Statistics for Analytes Detected in Soil Samples from 0 to $4 \mathrm{ft}$ Deep from the Fire Department Hose Training Facility

\begin{tabular}{|c|c|c|c|c|c|c|c|c|c|c|c|c|c|c|c|c|c|c|c|c|}
\hline 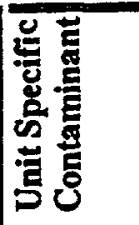 & & $\underline{\mathfrak{s}}$ & 5 & & 纹 & & & 幽 & & & 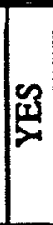 & & 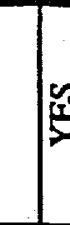 & & & & & & 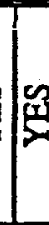 & \\
\hline 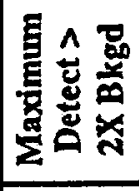 & & $\underline{\underline{\nu}}$ & & & 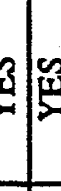 & $\underline{\underline{2}}$ & 战 & $\stackrel{2}{\mathbf{2}}$ & 舆 & & & 骨 & $\Phi$ & & $\mid$ & 監 & & & $\sqrt{1}$ & 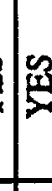 \\
\hline 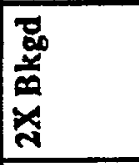 & & $\left.\mid \begin{array}{l}8 \\
0 \\
\hdashline\end{array}\right]$ & $=\frac{1}{2}$ & 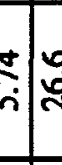 & : & $\int_{0}^{+}$ & 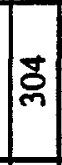 & 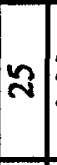 & $\begin{array}{l}: \\
:\end{array}$ & $\hat{i}_{0}$ & $\frac{8}{N}$ & $\overrightarrow{\mathbf{a}}$ & $\stackrel{0}{0}$ & $\mid \begin{array}{l}0 \\
\vdots \\
0 \\
0 \\
0\end{array}$ & 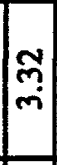 & $\stackrel{\infty}{m}$ & & & & 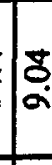 \\
\hline 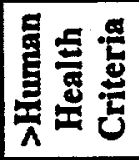 & & 甜 & & 结 & $\underline{x}$ & & & 幽 & & & 旡 & & 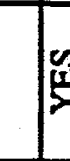 & & & & & & $\underline{\Sigma}$ & \\
\hline 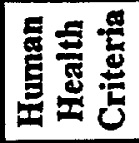 & & : & $\vec{m}$ & t. & $\frac{n}{0}$ & a & 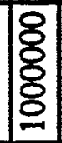 & 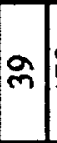 & 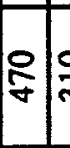 & 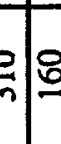 & ళ్ల్ల & 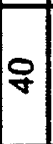 & ठ্्্ট్రిం & $\stackrel{\infty}{\infty}$ & 0 & స్ల్ల & in & & 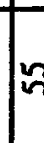 & ర్ల \\
\hline 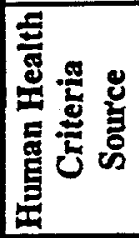 & & $\mid \begin{array}{l}- \\
0 \\
0 \\
0 \\
0 \\
0\end{array}$ & 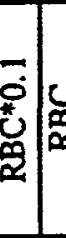 & & 要 & 竞 & 䯃 & 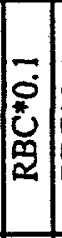 & & 管 & 㤩 & : & $\widehat{a}$ & 宽 & $\mid \begin{array}{l}\overrightarrow{0} \\
0 \\
0 \\
0 \\
0\end{array}$ & & & & & $\begin{array}{l}-3 \\
0 \\
0\end{array}$ \\
\hline 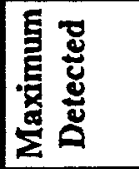 & & 总 & • & $\stackrel{m}{r}=$ & 子) & 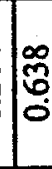 & $\cong$ & $\left|\begin{array}{l}\infty \\
\dot{y}\end{array}\right|$ & $-1:$ & $\stackrel{6}{0}$ & $\frac{8}{8}$ & $\stackrel{a}{\Xi}$ & \& & $\widetilde{\tilde{O}}$ & $\left|\begin{array}{l}0 \\
0 \\
m\end{array}\right|$ & $\mathbb{Z}$ & $=$ & $\begin{array}{l}\infty \\
a\end{array}$ & & 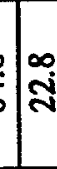 \\
\hline 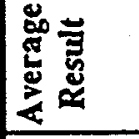 & & 号 & $\stackrel{0}{-}$ & $\stackrel{+}{+}[$ & 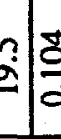 & $\frac{-6}{0}$ & $\mathfrak{N}$ & $\stackrel{m}{ \pm}$ & 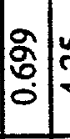 & 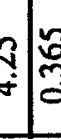 & 8 & $\begin{array}{c}0 \\
\infty \\
\infty\end{array}$ & $\Xi \frac{9}{\circ}$ & 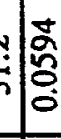 & $\stackrel{2}{=}$ & o & 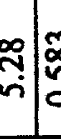 & & & ? \\
\hline 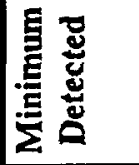 & & :0 & ज़े & $=10$ & $\mid \begin{array}{l}x \\
\ddot{c} \\
c\end{array}$ & 范 & $\vec{\infty}$ & $\approx$ & $\mid \begin{array}{l}0 \\
\vdots \\
0 \\
0\end{array}$ & ? & 这 & $\underset{m}{\infty}$ & $\frac{9}{8}$ & $\mid$ & $\begin{array}{l}5 \\
0 \\
0\end{array}$ & $\begin{array}{l}\infty \\
\text { in } \\
\text { in }\end{array}$ & $\vec{a}$ & & & $i$ \\
\hline 呟 & & 잉 & $\stackrel{0}{m}$ & $\stackrel{0}{2}$ & $\stackrel{0}{a}$ & $\frac{O}{\pi}$ & 응 & $\stackrel{0}{2}$ & 이요 & $=$ & 응 & 응 & $\begin{array}{ll}\circ \\
\vdots\end{array}$ & 2 & 응 & 응 & $=$ & 25 & & 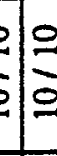 \\
\hline$\frac{\mathrm{z}}{\mathrm{z}}$ & 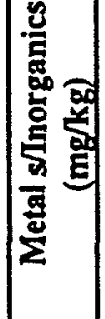 & $\frac{\tilde{E}}{\bar{E}}$ & 吾 & 递 & (1) & $\bar{\Phi}$ & $\frac{E}{0}$ & 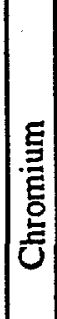 & 青 & : & ᄃ & 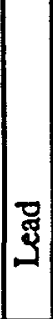 & 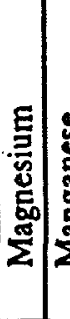 & 营 & 1 & 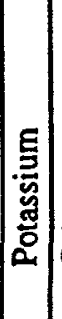 & os & & & : \\
\hline
\end{tabular}


Record of Decision for the Fire Department Hose Training Facility (904-113G)

Operable Unit (U)

WSRC-RP-97-171

Savaunah River Site Anril 1008

Revision

Table 3. Summary Statistics for Analytes Detected in Soil Samples from 0 to $4 \mathrm{ft}$ Deep from the Fire Department Hose Training Facility (Continued)

\begin{tabular}{|c|c|c|c|c|c|c|c|c|c|c|c|c|c|c|c|c|c|}
\hline 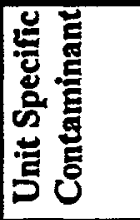 & & & 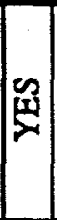 & & 通 & & & & & & & & & & & & \\
\hline 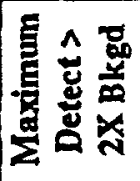 & & 鸹 & $\underline{\tilde{a}}$ & $\mid \begin{array}{l}\mathscr{E} \\
\mathscr{E}\end{array}$ & 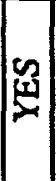 & 監 & $\stackrel{\infty}{\pi}$ & $\stackrel{\mathscr{d}}{\mathfrak{d}}$ & 既 & $\tilde{z}$ & $\mathfrak{\Xi}$ & 承 & 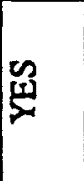 & 垒 & & 台 & $\stackrel{2}{21}$ \\
\hline 숭 & & 要 & $\mathrm{z}$ & $\mathbf{z}$ & 空 & 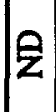 & 号 & 吾 & 妾 & 妾 & $\frac{Q}{z}$ & 要 & $\mathrm{z}$ & z & & 至 & 至 \\
\hline 量起焉 & & & $\left\{\begin{array}{l}\Omega \\
-1\end{array}\right.$ & & {$\left[\begin{array}{l}\mathscr{A} \\
\mid\end{array}\right.$} & & & & & & & & & & & & \\
\hline 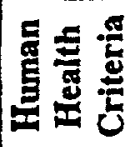 & & $\mid \begin{array}{l}\infty \\
\infty \\
\infty\end{array}$ & $|\infty| \infty \mid$ & $\left|\begin{array}{l}\mathbf{\infty} \\
\infty \\
\infty\end{array}\right|$ & z & 冓 & $\frac{8}{8}$ & 庹 & 站 & 逢 & \$్ర్రీ & 总 & $\mathscr{\infty}$ & 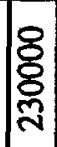 & & ర్ర్ర & 용ㅇㅇㅇㅛ \\
\hline 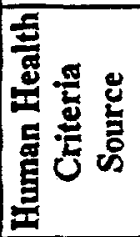 & & $\mid \begin{array}{l}u \\
\mathbf{g}\end{array}$ & 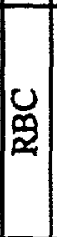 & 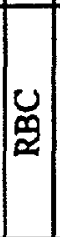 & & 㿸 & $\begin{array}{l}\overline{0} \\
0 \\
0 \\
\ddot{2}\end{array}$ & 垈 & $\mid \begin{array}{l}u \\
\mathscr{Q}\end{array}$ & 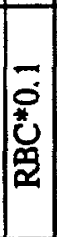 & 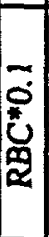 & $\begin{array}{l}\ddot{0} \\
0 \\
0\end{array}$ & $\begin{array}{l}\text { U } \\
2\end{array}$ & $\begin{array}{l}\square \\
0 \\
0 \\
2 \\
2\end{array}$ & & U & $\begin{array}{l}= \\
0 \\
0 \\
0 \\
0\end{array}$ \\
\hline 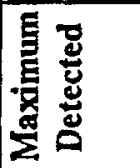 & & $\left|\begin{array}{l}0 \\
\dot{\alpha} \\
0\end{array}\right|$ & \pm & $\frac{}{m}$ & $\bar{\Xi}$ & $\frac{\partial}{2}$ & ?. & L & $\stackrel{\infty}{\infty}$ & İ & $\stackrel{m}{m}$ & $\cong$ & $\stackrel{\simeq}{=}$ & 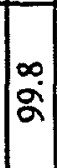 & & ñ & ల్ \\
\hline 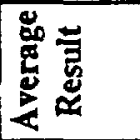 & & $\mid \stackrel{\circ}{\stackrel{2}{~}}$ & $\bar{\nabla}$ & 恶 & 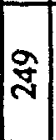 & ฟิ & 总 & $\ddot{\vec{N}}$ & $\approx$ & 芯 & $\tilde{n}$ & 文 & 守 & $\stackrel{\sim}{\sim}$ & & $\frac{\tilde{f}}{v i}$ & $\begin{array}{l}\Omega \\
\sim\end{array}$ \\
\hline 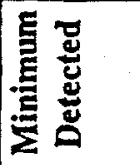 & & $\begin{array}{l}0 \\
\dot{\alpha} \\
\dot{\alpha}\end{array}$ & \pm & $\frac{5}{m}$ & $\bar{N}$ & $\frac{a}{\sim}$ & $\begin{array}{c}0 \\
8\end{array}$ & $\prod_{m}^{\infty}$ & $\cong$ & 涪 & ga & $\cong$ & $\stackrel{\beth}{\beth}$ & 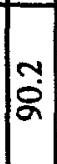 & & $\begin{array}{l}\mathbf{D} \\
0 \\
0\end{array}$ & i̊n. \\
\hline 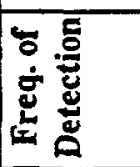 & & $\underline{0}$ & 인 & 인 & 우 & 음 & $\underline{=}$ & $\frac{0}{N}$ & $\equiv$ & $\equiv$ & $\frac{0}{2}$ & $\underline{2}$ & $=$ & 을 & & $\begin{array}{l}\frac{O}{N} \\
\text { N }\end{array}$ & 을 \\
\hline 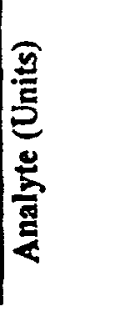 & 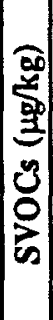 & 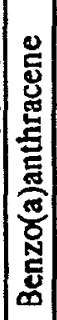 & 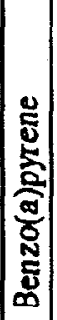 & 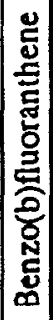 & 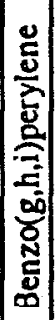 & 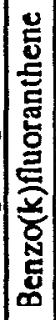 & 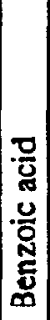 & 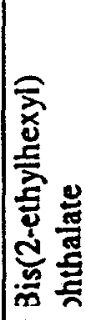 & 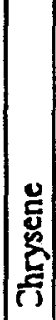 & 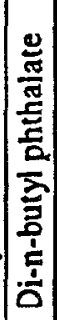 & 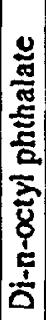 & 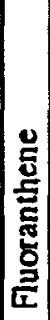 & 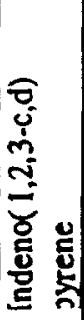 & $\mid$\begin{tabular}{|c|}
$\mid$ \\
$y$ \\
$\frac{c}{5}$ \\
$c$
\end{tabular} & 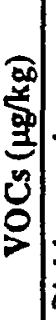 & 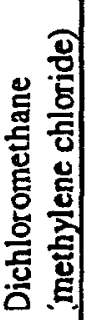 & : \\
\hline
\end{tabular}


Table 4. Summary Statistics for Analytes Detected in Soil Samples from $>4 \mathrm{ft}$ Deep from the Fire Department Hose Training Facility

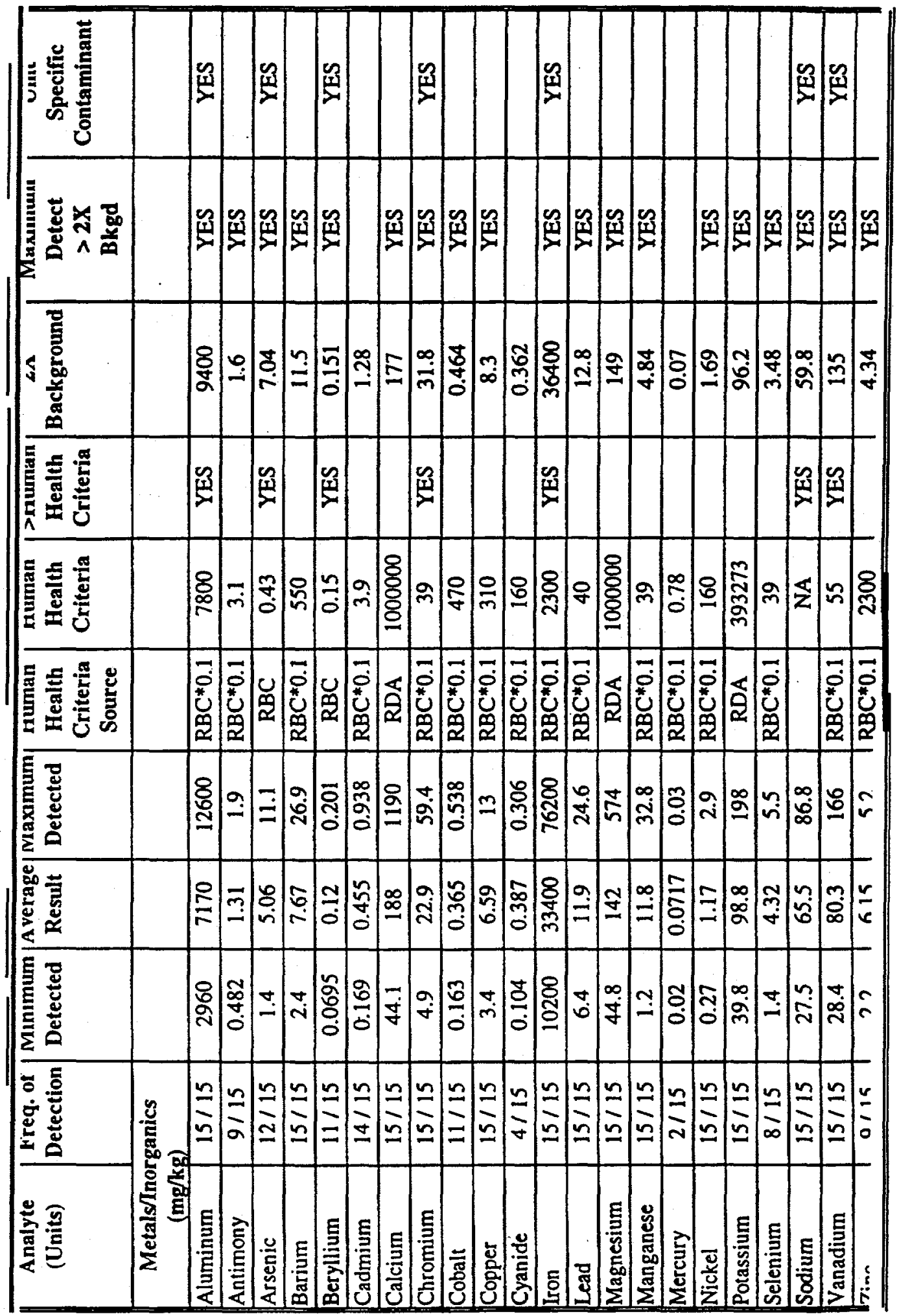


Table 4. Summary Statistics for Analytes Detected in Soil Samples from $>4 \mathbf{f t}$ Deep from the Fire Department Hose Training Facility (Continued)
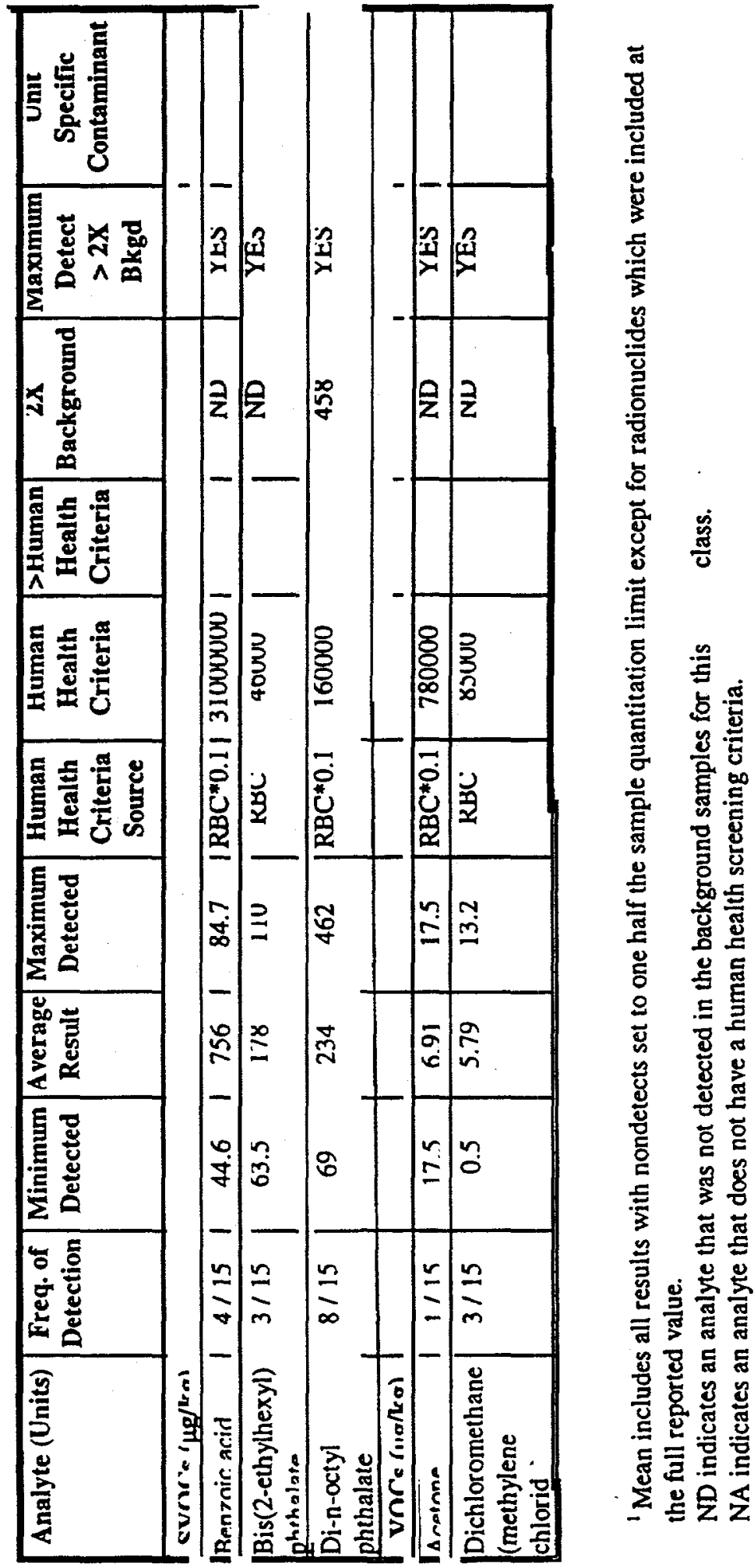
As a component of the remedial investigation process, a baseline risk assessment was prepared for the FDHTF. The baseline risk assessment consists of human health and ecological risk assessments. Summary information for the human health and ecological risk assessments follows.

\section{HUMAN HEALTH RISK ASSESSMENT}

The human health risk assessment characterizes both the potential risk from exposure to carcinogenic substances and adverse health effects from noncarcinogens to human receptors exposed to unit-related constituents under current and future land use conditions (Figure 6). Figure 6 indicates the future land use for N-Area (Central Shops) as recommended by the Citizens Advisory Board which was based on current nuclear industrial areas with a buffer. The risks listed in this section were derived from the BRA (WSRC, 1997a) which used the data obtained from the RFI/RI characterization.

The BRA designates the Constituents of Potential Concern (COPCs) based on a conservative screen against background concentrations and the relative potential of the chemicals to cause toxic or carcinogenic effects. Constituents which have concentrations in soil which produce a threshold risk less than the risk-based concentration levels are screened from further analysis. Threshold risk is defined as constituent concentrations that exceed either a cancer risk of $1 \times 10^{-6}$ or a hazard quotient (HQ) of 1 . An HQ of 0.1 was actually used for screening within the BRA to account for potential additive effects for noncarcinogenic constituents. Three land use assumptions were made to describe the human receptors that may be exposed to unitrelated constituents. Potential receptors are expected to differ for the current and future land use scenarios. The possible receptor under the current land use scenario includes the known on-unit worker. The possible receptors under the future land use scenario include the on-unit industrial worker and the on-unit resident (adult and child).

Based on the results of the risk assessment, COPCs that contribute significantly to a pathway having a significant human cancer risk or human noncarcinogenic hazard or are determined to pose unacceptable ecological risk are designated as preliminary constituents of concern (COCs). The preliminary COCs are further defined as either primary or secondary COCs. 
Final COCs are developed through an uncertainty analysis to inform decision-makers about the relative significance of the preliminary COCs, and to help focus on risk decisions.

Preliminary Human Health primary COCs are constituents in a total exposure pathway (media/receptor/route) with a cumulative noncancer hazard greater than 3 or a cumulative ELCR greater than $1 \times 10^{-4}$. Primary COCs have a constituent-specific noncancer hazard greater than or equal to 0.1 or a cancer risk greater han $1 \times 10^{-6}$.

Preliminary Human Health secondary COCs are chemicals in a total exposure pathway (media/receptor/route) with a cumulative noncancer hazard between 1 and 3 or a cumulative Excess Lifetime Cancer Risk (ELCR) between $1 \times 10^{-6}$ and $1 \times 10^{-4}$. Secondary COCs have a constituent-specific noncancer hazard greater than or equal to 0.1 or a cancer risk greater than or equal to $1 \times 10^{-6}$.

Carcinogenic risks are estimated as the incremental probability of an individual developing cancer over a lifetime as a result of pathway-specific exposure to cancer-causing contaminants. The risk to an individual resulting from exposure to non-radioactive chemical carcinogens is expressed as the increased probability of cancer occurring over the course of a 70 year lifetime. Cancer risks are related to the EPA target risk range of one in ten thousand $\left(1 \times 10^{-4}\right)$ to one in one million $\left(1 \times 10^{-6}\right)$ for incremental cancer risk at National Priorities List

- $\quad$ sites. Risk levels greater than $1 \times 10^{-6}$ require a risk management decision where specific actions to reduce risk may be considered while cancer risk levels below $1 \times 10^{-6}$ are considered to be insignificant.

Non-carcinogenic effects are also evaluated to identify a level at which there may be concern for potential non-carcinogenic health effects. The hazard quotient, which is the ratio of the exposure dose to the reference dose (RfD), is calculated for each contaminant. Hazard quotients are summed for each exposure pathway to determine the specific hazard index (HI) for each exposure scenario. If the $\mathrm{HI}$ exceeds unity (1.0), the potential exists that adverse health effects might occur.

The following sections discuss the excess lifetime cancer risk (ELCR) and combined HI values that were determined in the BRA for current workers, future industrial workers, and the future residential child/adult. Figure 7 shows these values graphically. Tables 5 through 8 
show the Reasonable Maximum Exposure (RME) risk characterization summaries for the surface soil ( $0-1$ '), subsurface soils $(0-4$ '), background surface soil $(0-1$ '), and background subsurface soil $\left(0-4^{\prime}\right)$.

\section{Current Worker}

The current worker was evaluated at the 0 to $0.3 \mathrm{~m}(0$ to $1 \mathrm{ft})$ soil interval only. The total excess lifetime cancer risk level for the current worker is $4 \times 10^{-9}$ and the hazard index is $7 \times 10^{-5}$. Therefore, the current worker is not at risk while working at this unit.

\section{Future Industrial Worker}

The future industrial worker was evaluated at the 0 to $0.3 \mathrm{~m}(0$ to $1 \mathrm{ft})$ and 0 to $1.2 \mathrm{~m}(0$ to 4 $\mathrm{ft})$ soil intervals. For the 0 to $0.3 \mathrm{~m}(0$ to $1 \mathrm{ft})$ soil interval, the total excess lifetime cancer risk is $9 \times 10^{-7}$ and the. hazard index is $3 \times 10^{-3}$. Therefore, the future industrial worker will not be at risk while working at the unit based on the evaluation of the surface soils. For the 0 to $1.2 \mathrm{~m}$ ( 0 to $4 \mathrm{ft}$ ) soil interval, the total excess lifetime cancer risk is $4 \times 10^{-6}$ and the hazard index is 0.2 . The pathways which contribute the most to this receptor are soil ingestion and dermal contact, each showing a cancer risk of $2 \times 10^{-6}$. The secondary COCs for these pathways are arsenic ( $84 \%$ of the risk for the ingestion pathway) and beryllium ( 54 percent of the risk for the dermal contact pathway).

\section{Future Residential Child/Adult}

The residential scenario was evaluated at the 0 to $0.3 \mathrm{~m}(0$ to $1 \mathrm{ft})$ and the 0 to $1.2 \mathrm{~m}(0$ to 4 $\mathrm{ft}$ ) soil intervals. At the 0 to $0.3 \mathrm{~m}(0$ to $1 \mathrm{ft})$ soil interval, the total excess lifetime cancer risk is $1 \times 10^{-5}$ and the hazard index is 0.5 . The secondary COC is benzo(a)pyrene, from ingestion of produce (risk of $1 \times 10^{-5}$ ).

For the 0 to $1.2 \mathrm{~m}\left(0\right.$ to $4 \mathrm{ft}$ ) soil interval, the total excess lifetime cancer risk is $8 \times 10^{-5}$ and the hazard index is 4 . The pathways which significantly contribute to this receptor are ingestion $\left(2 \times 10^{-5}\right)$, dermal exposure $\left(5 \times 10^{-6}\right)$, and the ingestion of produce $\left(5 \times 10^{-5}\right)$. In the ingestion pathway, the cancer secondary COCs are arsenic (which contributes $84 \%$ of the risk) and benzo(a)pyrene. The hazard index for the ingestion pathway is 2.4 and the 
secondary COCs are iron (which contributes to $78 \%$ of the hazard); arsenic and vanadium. The combined risk for the ingestion of produce is $5 \times 10^{-5}$, the secondary COCs are arsenic and benzo(a)pyrene, of which arsenic contributes $98 \%$ of the risk. A summary of the human health risks for soil and produce for the various land use scenarios is given in Table 9. 
Figure 6. Future Land Use at N-Area (Central Shops)

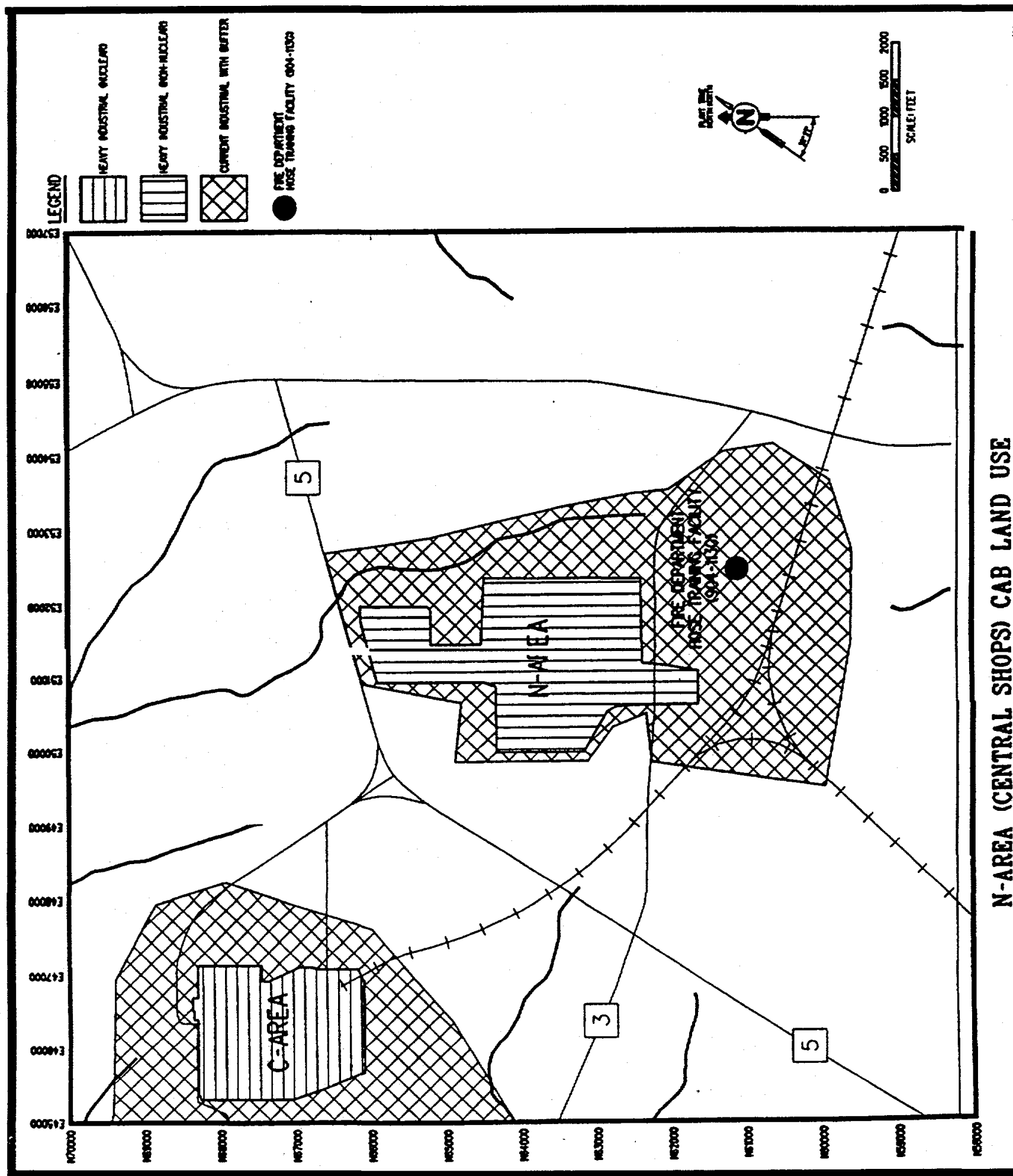


Figure 7. Summary of Chemical Risks and Hazards Across Pathways and Receptors for the FDHTF
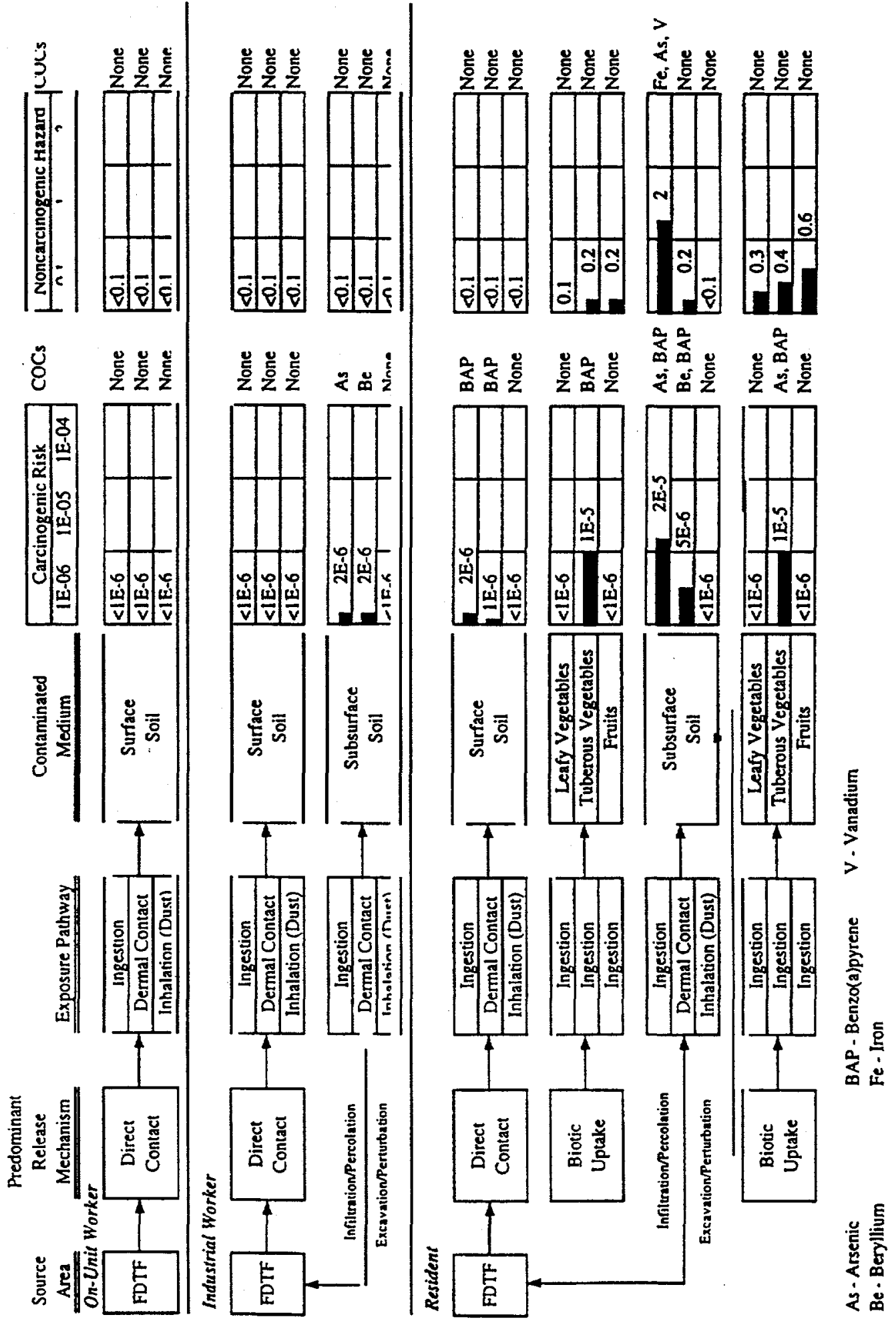
Table 5. RME Risk Characterization Summary: FDHTF Surface Soil (0 to 1 foot)

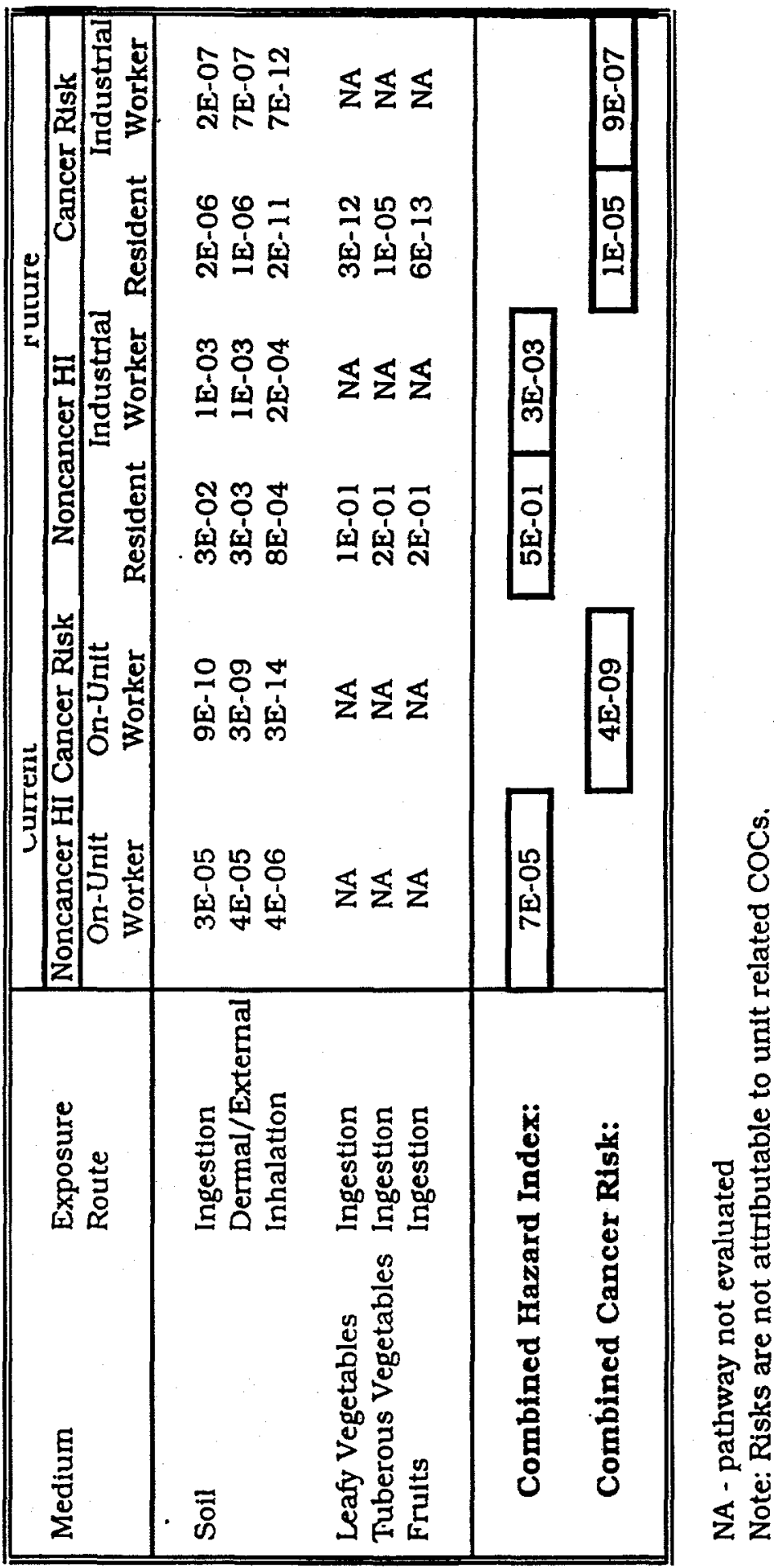


Table 6. RME Risk Characterization Summary: FDHTF Subsurface Soil (0 to 4 foot)

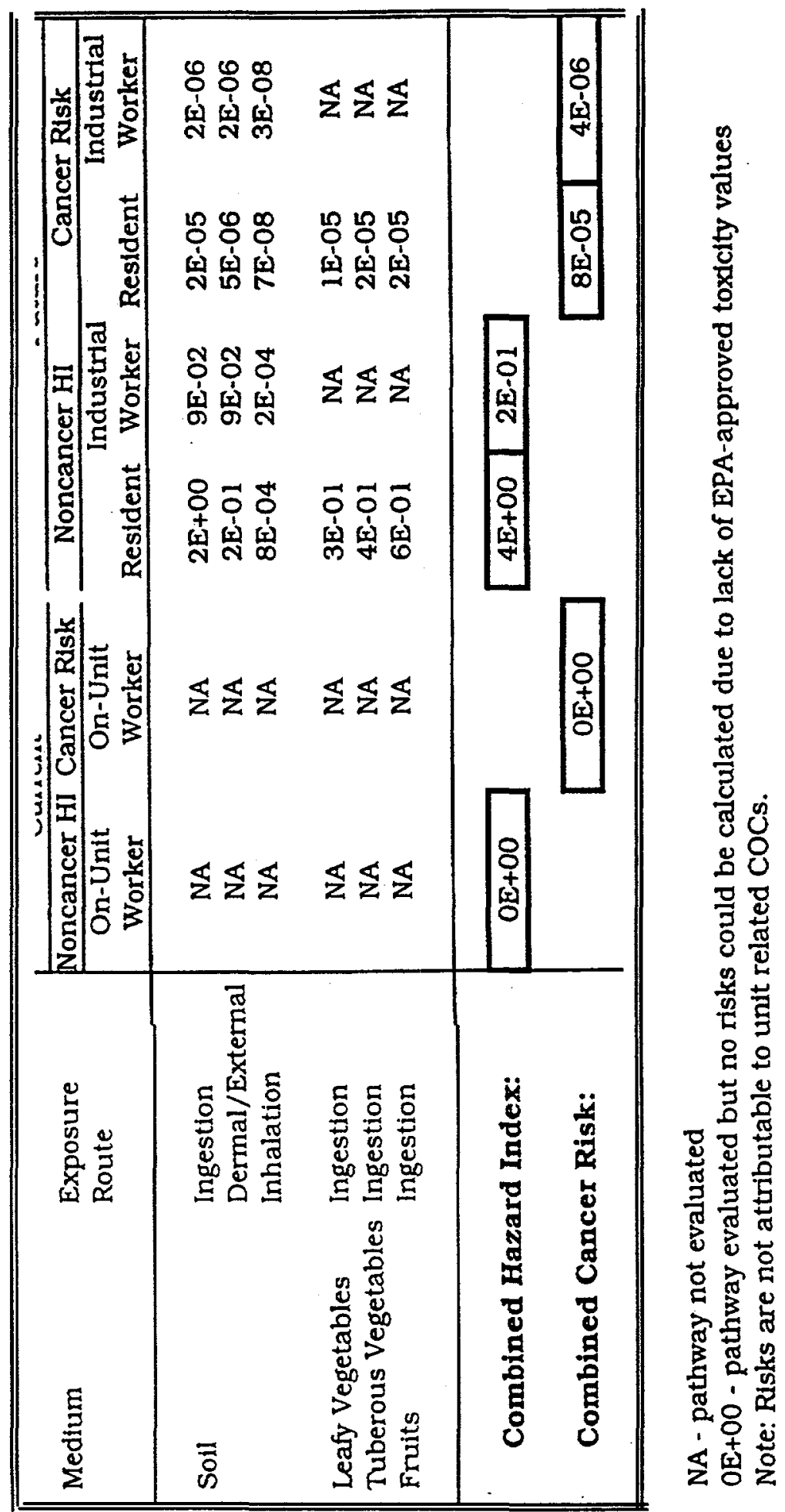


Table 7. RME Risk Characterization Summary: FDHTF Background Surface Soil (0 to 1 foot)

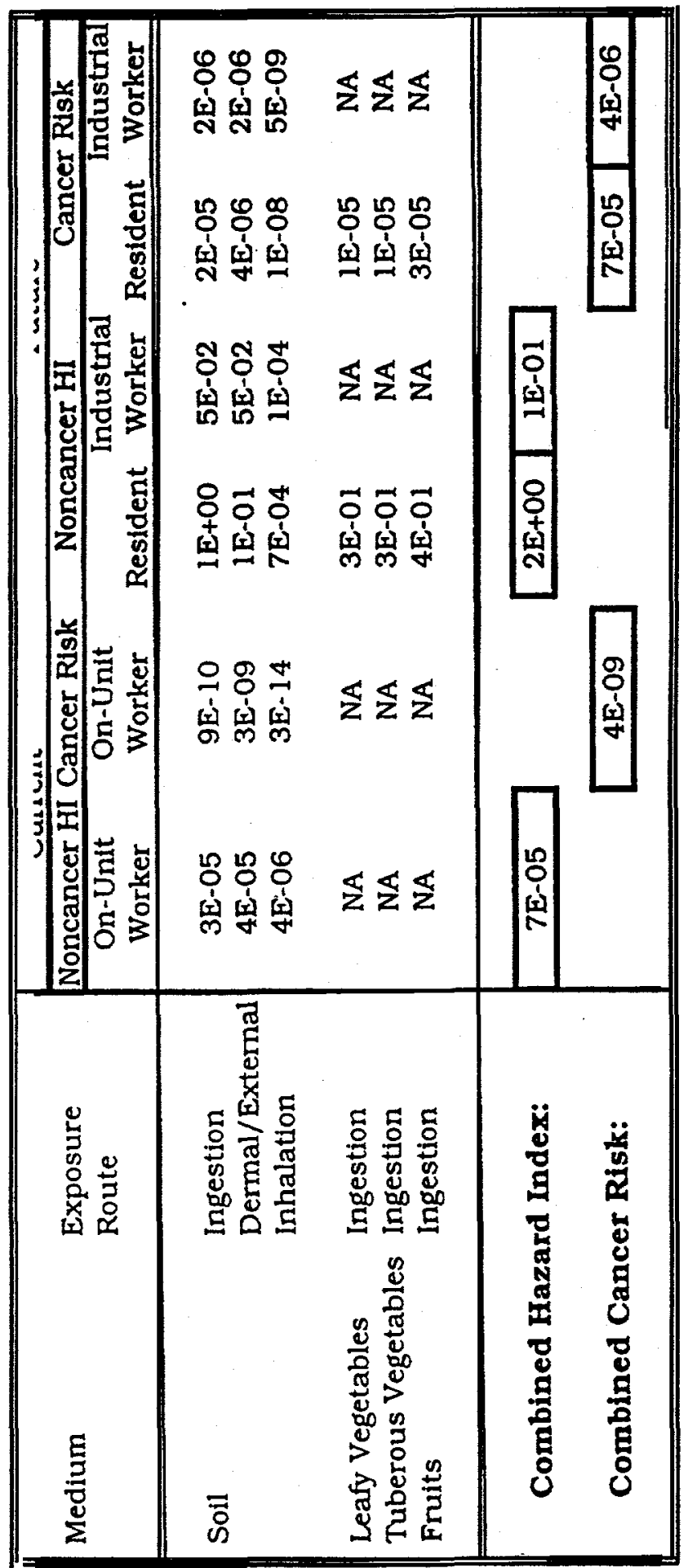


Record of Decision for the Fire Department Hose Training Facility (904-113G)

Operable Unit (U)

WSRC.RP-97-171

Operable Unit (U)

Revision 1

Table 8. RME Risk Characterization Summary: FDHTF Background Subsurface Soil (0 to 4 foot)

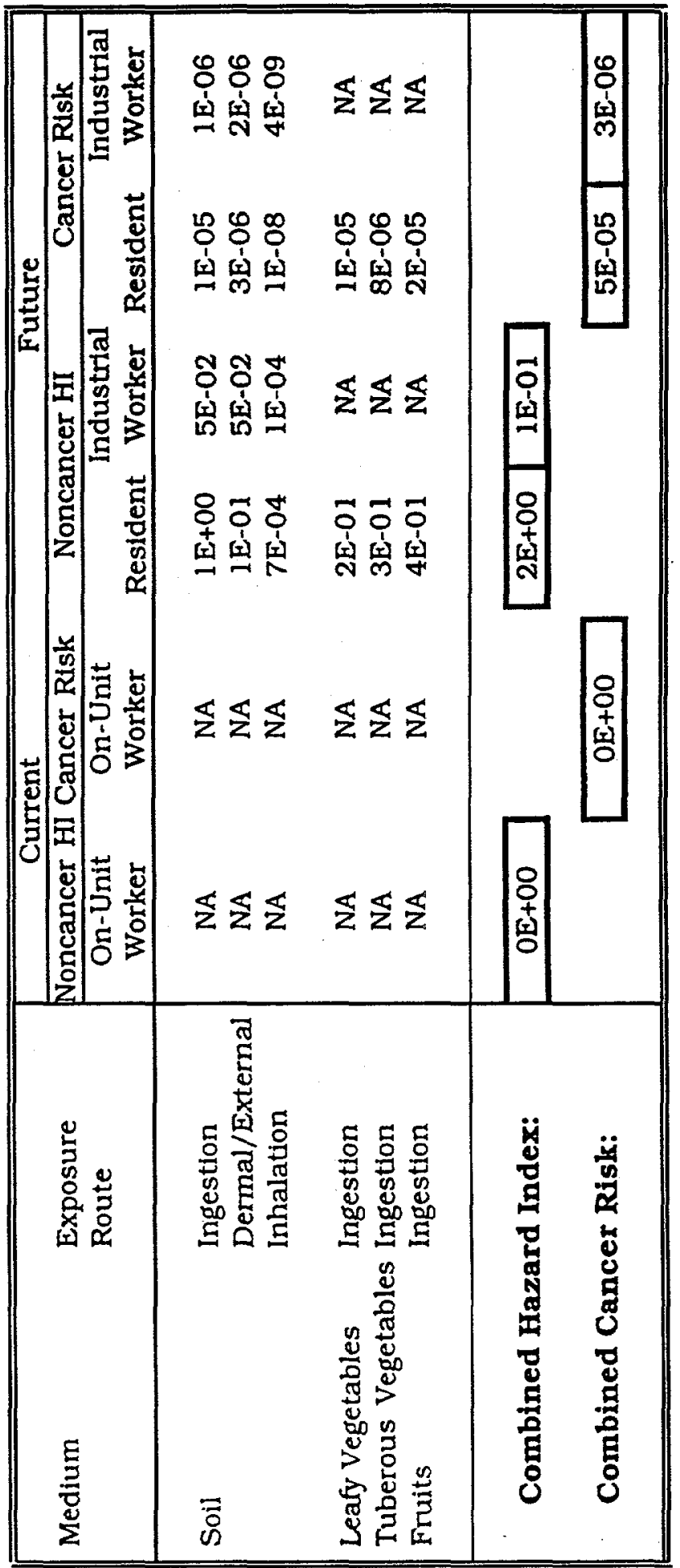

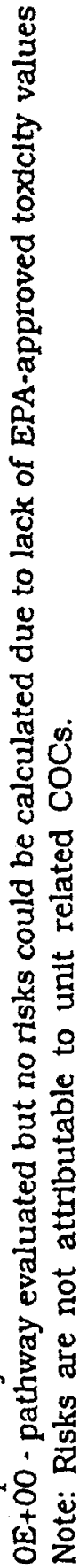


Table 9. Health-Based COCs for Soil and Produce Fire Department Hose Training Facility

\begin{tabular}{|c|c|c|}
\hline Media & $\overline{0 \text {-1 ft Soil Interval }}$ & 0-4 ft Soil Interval \\
\hline Sóll $\quad$ L & MtER & TRiskJHazand it \\
\hline $\begin{array}{l}\text { - Current On-Unit Worker } \\
\text { Hypothetical Industrial Worker } \\
\text { Hypothetical On-Unit Resident }\end{array}$ & Benzo(a)pyrene (ELCR $=3 \times 10^{-6}$ ) & $\begin{array}{l}\left.\text { Arsenic (ELCR }=2 \times 10^{-6}\right) \\
\left.\text { Beryllium (ELCR }=1 \times 10^{-6}\right) \\
\text { Arsenic (HQ }=0.3) \\
\text { Arsenic (ELCR }=1 \times 10^{-5} \text { ) } \\
\text { Beryllium (ELCR }=3 \times 10^{-6} \text { ) } \\
\text { Iron (HQ }=2 \text { ) } \\
\text { Vanadium (HQ }=0.3) \\
\text { Benzo(a)pyrene (ELCR }=2 \times 10^{-6} \text { ) }\end{array}$ \\
\hline \multicolumn{3}{|l|}{ 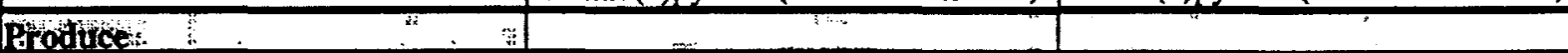 } \\
\hline Hypothetical Resident & Benzo(a)pyrene (ELCR $=1 \times 10^{-3}$ ) & $\begin{array}{l}\left.\text { Arsenic (ELCR }=4 \times 10^{-6}\right) \\
\text { Benzo(a)pyrene }\left(E L C R=1 \times 10^{-5}\right)\end{array}$ \\
\hline
\end{tabular}

Note: $E L C R=$ excess lifetime cancer risk, $\mathrm{HQ}=$ Hazard Quotient

\section{ECOLOGICAL RISK ASSESSMENT}

The ecological BRA for the FDHTF evaluated the likelihood of harmful effects to ecological receptors from exposure to contaminants in soil. The receptors in the FDHTF food web that were evaluated include terrestrial plants, earthworms, meadow voles, short-tailed shrews, American robins, and red-tailed hawks. These receptors serve as assessment endpoints for the risk to plant and animal populations and ecosystems at FDHTF.

The evaluation of ecological risk was conducted according to relevant EPA headquarters, US EPA Region IV, SCDHEC, and Westinghouse Savannah River Company guidance. The assessment methods follow the EPA Framework for Ecological Risk Assessments (EPA, 1992b) and draft Ecological Risk Assessment Guidance for Superfund (EPA, 1994b).

Ecological Constituents of Potential Concern (COPCs) were identified from among constituents detected at FDHTF, and incomplete exposure pathways were eliminated. The risk from COPCs in FDHTF surface soil was evaluated only for those pathways resulting in ingestion of soil or those food items exposed directly or indirectly to soil. COPCs are those 
constituents whose maximum measured concentrations exceeded a toxicity screening value for ecological receptors and $2 \mathrm{X}$ the background mean concentration.

Based on field reconnaissance, the principal ecological communities at FDHTF were characterized as maintained grassy fields with scattered mature trees. Most receptors, exposure classes, and/or species evaluated in the ecological risk assessment were observed at the unit or potentially reside or forage there. No threatened, endangered and sensitive species are expected to be exposed to COPCs in surface soil at FDHTF.

Six assessment endpoints representing environmental values to be protected in accordance with two policy goals were evaluated at the FDHTF. The risks to the FDHTF populations and ecosystems were evaluated by estimating the risk to populations of the six indicator receptors [terrestrial vegetation, earthworms, meadow vole (proxy for herbivorous mammals), short-tailed shrew, American robin, and red-tailed hawk] according to ecological relevance, susceptibilit $y$, accessibility to prediction or measurement, and relevance to policy goals.

For the evaluation of risk to the FDHTF populations and ecosystems, decision rules are stated in terms of HQs. HQs compare estimates of exposure based on site measurements (e.g., RME concentrations of COPCs in the source media [surface and subsurface soil]) to measures of effect (e.g., test concentrations associated with levels of adverse effect on ecological receptors).

Measured concentrations of ecological COPCs in surface soil are used to estimate the RME concentrations and doses for ecological receptors. Published toxicity-benchmark data are used to derive COPC concentrations associated with levels of adverse effect on ecological receptors at the FDHTF.

HQs for current and future exposure of ecological receptors to COPCs in surface and subsurface soil were calculated and used to estimate risk. No HQs exceeded 1.0 in surface soil $(0-0.3 \mathrm{~m}[0-1.0 \mathrm{ft}])$; therefore, there are no ecological risks for current conditions. The five metals (aluminum, cadmium, chromium, selenium, and vanadium) exceeding an HQ of 1.0 are the COPCs associated with future conditions at the FDHTF. 
The weight-of-evidence analysis and evaluation of uncertainty for ecological COPCs with HQs exceeding 1.0 resulted in rejection of all five metals as sources of significant risk to ecological receptors at the exposure unit.

\section{UNCERTAINTY}

The risk and hazard to the current worker, future on-unit industrial worker, and the future onunit resident are summarized below. Preliminary COCs identified during the risk assessment are evaluated through an uncertaint $y$ analysis to determine final COCs. Remedial Goal Options (RGOs) are developed for the list of final COCs which become the basis of and the focus for remediation.

Under the current land use, no primary or secondary preliminary COCs were identified for the surface soil. Under future industrial land use, arsenic, beryllium, iron, vanadium, and benzo(a)pyrene were identified as secondary preliminary COCs for subsurface soils. Following the uncertainty analysis, no constituents were retained as final COCs and no RGOs were developed. Key uncertainties for each preliminary $\mathrm{COC}$ are summarized below.

\section{Current Worker}

The current worker is not at risk while working at this unit because the ELCR risk is below $1 \times 10^{-6}$ and the $\mathrm{HI}$ is below 1 .

\section{Future Industrial Worker}

Arsenic and beryllium were identified as secondary $\mathrm{COCs}$ for the future industrial worker for the 0 to 4 -foot soil depth interval. Although arsenic and beryllium were identified as preliminary COCs following the risk assessment, there is uncertainty that the concentration terms used to calculate unit risk are more representative of background risk. Arsenic was detected 9 out of 10 times in unit subsurface soils with a concentration range of 1.2 to 7.3 $\mathrm{mg} / \mathrm{kg}$. Comparatively, arsenic was detected in background subsurface 10 out of 10 times with concentrations ranging from 0.82 to $6.9 \mathrm{mg} / \mathrm{kg}$. The exposure point concentration for arsenic in unit subsurface soils is $6.0 \mathrm{mg} / \mathrm{kg}$, while the background exposure point concentration is $5.32 \mathrm{mg} / \mathrm{kg}$. 
Beryllium in subsurface soils was detected 8 out of 10 times at the unit with concentrations ranging from 0.06 to $0.20 \mathrm{mg} / \mathrm{kg}$, while beryllium was detected 10 out of 10 times in the background with a concentration range of 0.05 to $0.20 \mathrm{mg} / \mathrm{kg}$. The exposure point concentration for beryllium in unit subsurface soils is $0.15 \mathrm{mg} / \mathrm{kg}$, while the background exposure point concentration is $0.13 \mathrm{mg} / \mathrm{kg}$.

The unit data and background data demonstrate that there is no difference between unit and background concentrations of arsenic and beryllium. The similar concentration terms further demonstrate that the risk for both the unit and background would not be significantly different. Therefore, neither arsenic nor beryllium were retained as a final COCs.

\section{Future Residential Child/Adult}

The residential scenario was evaluated separately for the 0 to $0.3 \mathrm{~m}(0$ to $1 \mathrm{ft})$ and the 0 to 1.2 $\mathrm{m}(\mathrm{O}$ to $4 \mathrm{ft}$ ) soil intervals. Benzo(a)pyrene was identified as a secondary preliminary COC for both soil intervals. For subsurface soils ( 0 to $4 \mathrm{ft}$ ), arsenic, beryllium, iron, and vanadium were identified as secondary preliminary COCs. The uncertainty associated with each preliminary COC is discussed in further detail below.

\section{Arsenic and Beryllium}

As discussed for the future industrial worker, the unit data and background data demonstrate that there is no difference between unit and background concentrations of arsenic and beryllium. The similar concentration terms further demonstrate that the risk for both the unit and background for the future resident would not be significantly different. Therefore, neither arsenic nor beryllium were retained as final COCs.

Iron

Iron is a naturally occurring element that is abundantly distributed in soils. Iron was detected in subsurface soils in both the unit and background samples 10 out of 10 times. Concentrations of iron in unit subsurface soils ranged from $1480 \mathrm{mg} / \mathrm{kg}$ to $44,000 \mathrm{mg} / \mathrm{kg}$ and $1700 \mathrm{mg} / \mathrm{kg}$ to $22,700 \mathrm{mg} / \mathrm{kg}$ in background subsurface soils (Tables 10 and 11 ). The maximum detected value for both the unit and background subsurface soils was used for the 
exposure point concentration. Similarly, exposure to iron in both the unit and background subsurface soils would result in the designation of iron as a secondary COC. The designation of iron as a secondary COC is based on the use of a provisional toxicity value for iron, which is extremely conservative. The USFDA daily value for iron is $18 \mathrm{mg} /$ day which corresponds to a recommended daily dose of $0.26 \mathrm{mg} / \mathrm{kg} /$ day. In order to ingest this amount of iron from soil, the concentration of iron would have to be on the order of $180,000 \mathrm{mg} / \mathrm{kg}$. The exposure point concentration for subsurface soil for the unit $(44,000 \mathrm{mg} / \mathrm{kg})$ and background $(22,700 \mathrm{mg} / \mathrm{kg})$ are both more than an order of magnitude lower than $180,000 \mathrm{mg} / \mathrm{kg}$, indicating that iron in the soil is very unlikely to be of concern at the FDHTF. Therefore, iron was not retained as a final $\mathrm{COC}$. 
Record of Decision for the Fire Department Hose Training Facility (904-113G)

WSRC-RP-97-171

Operable Unit (U)

Revision 1

Table 10. Summary Statistics for Soil Background Concentrations from 0 to $1 \mathrm{ft}$ in the FDHTF

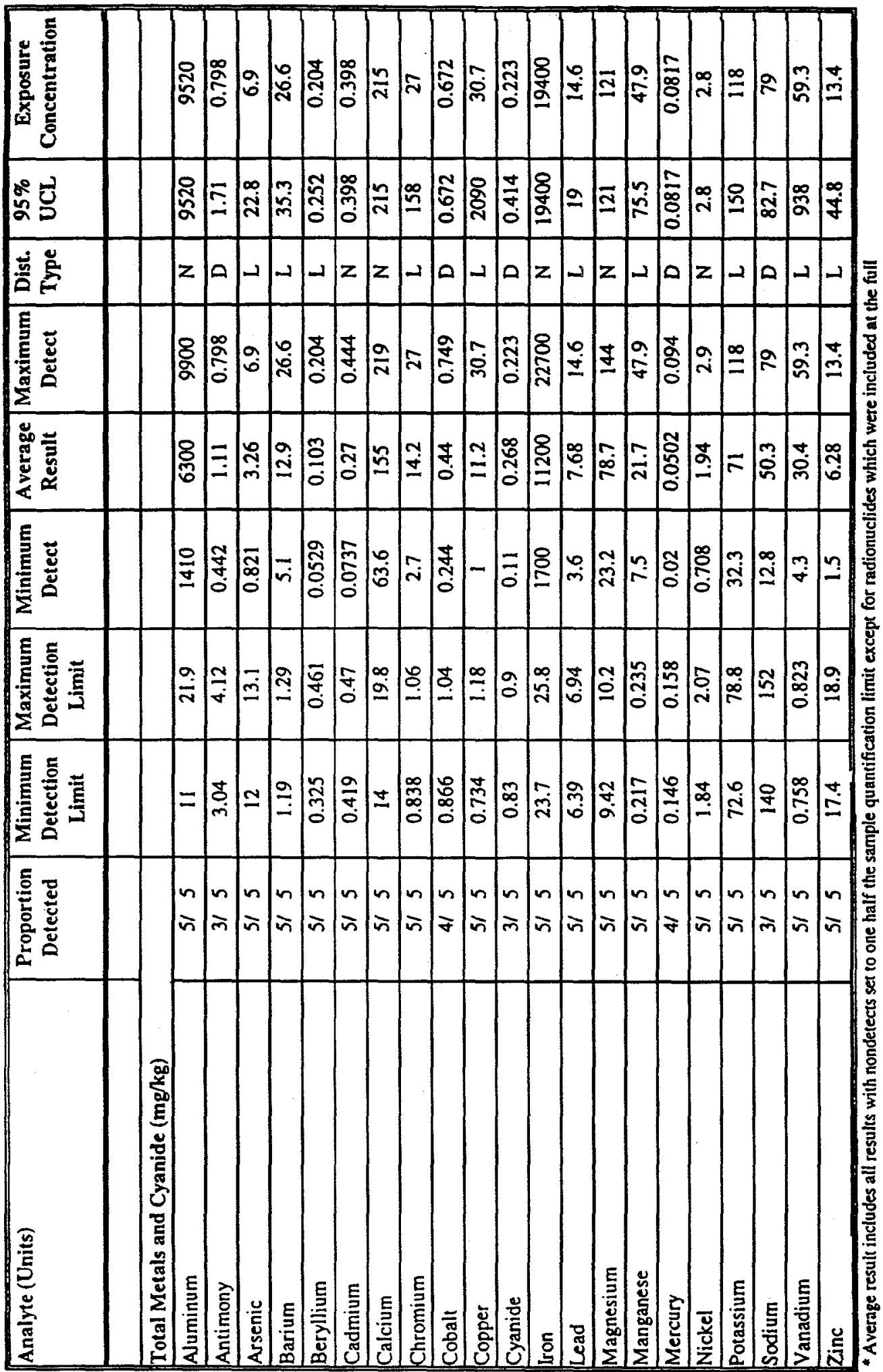

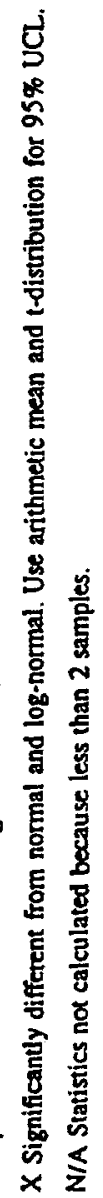




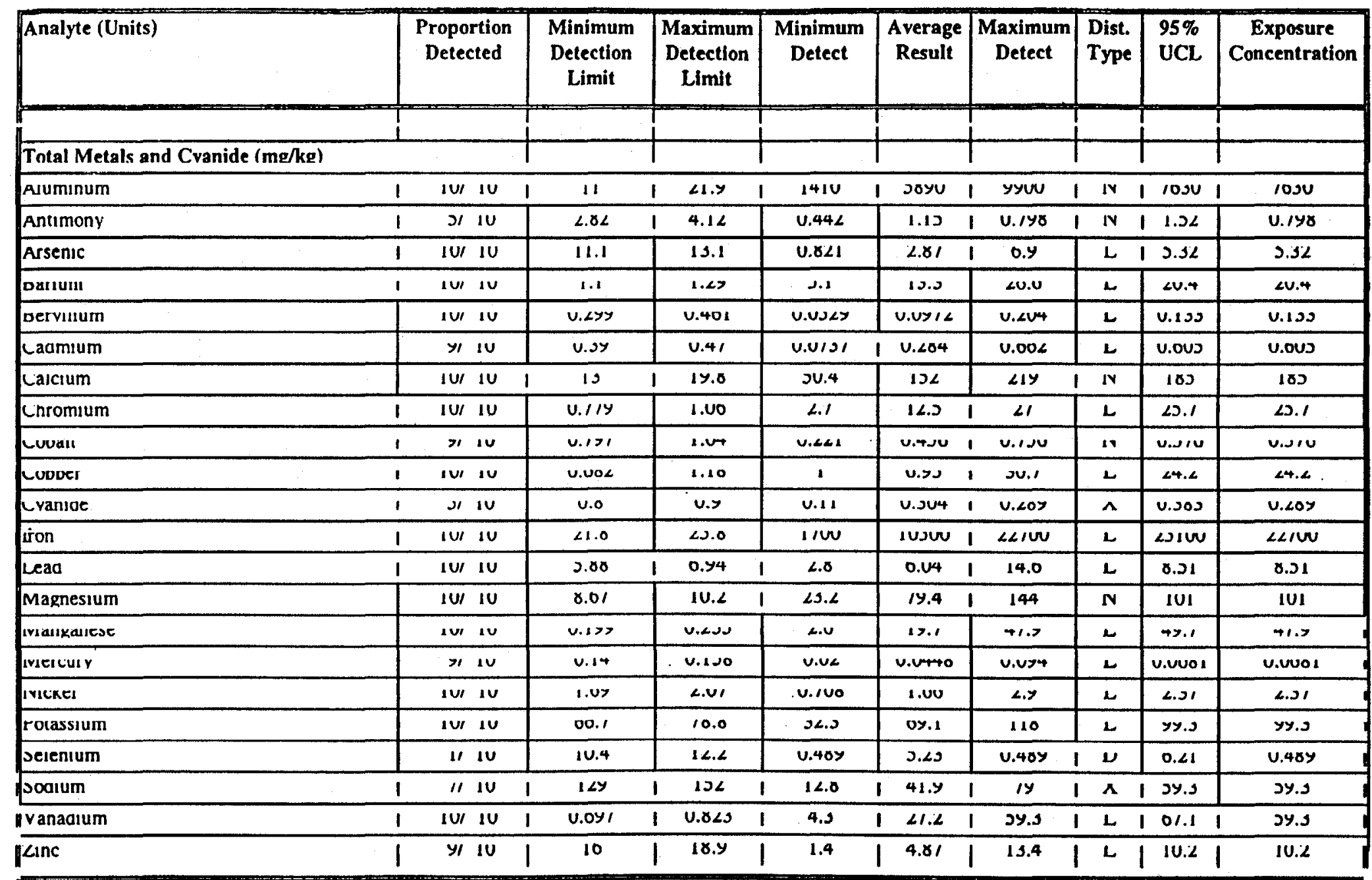

- Average result includes all results with nondetects set to one half the sample quantification limit except for radionuclides which were included at the full reported value.

Population Distribution Codes:

D Fewer than 5 or $50 \%$ detects. Treated as normal.

L Log-normal distribution.

N Normal distribution.

2 Population includes zero or negative results, treatod as normal.

$X$ Significantly different from normal and log-normal. Use arithmetic mean and t-distribution for $95 \%$ UCL. 
Vanadium

Vanadium is a naturally occurring metal which is abundant in soils at SRS. Vanadium was detected in subsurface soils in both the unit and background samples 10 out of 10 times. Concentrations of vanadium ranged from $3.6 \mathrm{mg} / \mathrm{kg}$ to $84.6 \mathrm{mg} / \mathrm{kg}$ in unit soils and $4.3 \mathrm{mg} / \mathrm{kg}$ to $59.3 \mathrm{mg} / \mathrm{kg}$ in background soils (Tables 10 and 11). The exposure point concentration for vanadium in subsurface soils for the unit and background is $84.6 \mathrm{mg} / \mathrm{kg}$ and $59.3 \mathrm{mg} / \mathrm{kg}$, respectively. Vanadium was only considered a secondary COC because it slightly exceeds an HQ of 0.1 in unit soils. The HQ for ingestion of vanadium in unit soils is 0.16 , while the HQ for ingestion of vanadium in background soils is 0.11 . Based on the frequency of detection in both the unit and background soils, and the similar concentration ranges and hazard quotients, it is highly unlikely that vanadium is unit related and should be of concern at the FDHTF. Therefore, vanadium was not retained as a final COC.

\section{Benzo(a)pyrene}

Although benzo(a) pyrene was retained as a secondary preliminary COC for both surface $\left(0-1^{\prime}\right)$ and subsurface soils $\left(0-4^{\prime}\right)$, it was only detected once in surface soils. Because of the single detection of benzo(a)pyrene, heterogeneous distribution and limited data should be considered. The FDHTF is a small area approximately 20 by 40 feet in size. According to site records, contaminated soils were removed from the facility in 1982 and 1984, thereby removing the primary source of cont amination. A total of five borings were drilled within the boundaries of the unit which provided a sufficient number of samples for the small area of concern to characterize the unit and adequately define the risk to human health and the environment. Benzo(a)pyrene was detected in 1 out of 5 surface soil samples, 1 out of 10 subsurface soil samples, and 1 out of 25 all-depth samples. Because the exposure point concentration is the single observed value, the risk of $3 \times 10^{-6}$ for the unlikely residential land use is based on the maximum detected concentration value. It is highly unlikely that benzo(a)pyrene should be of concern for the FDHTF because potential hot spots were addressed by representative sampling and because of the low $(<5 \%)$ frequency of detection. Therefore, benzo(a)pyrene was not retained as a final COC. 
Other Uncertainties

Food chain exposures and risk were projected in the BRA by means of uptake (partitioning) models. Uncertainty is inherent in each step of the food chain uptake models. Such models are based on studies of plant and animal uptake of constituents into the receptor of interest and are thus reliant upon a set of conditions that were present in the study environment. Precipitation and other weather-related factors, the chemistry of the soil and water, and other factors that existed in the uptake study may or may not relate well to the conditions present at the waste unit. The uncertainties resulting from the use of food chain uptake models are likely to be considerable. Because of the assumptions and uncertainties associated with the food chain pathway, the risk from produce is only considered when inclusion of the produce risk would determine whether the constituent is a final $\mathrm{COC}$ following the uncertaint $\mathrm{y}$ analysis. Because no final COCs were retained for the FDHTF, RGOs for risk from produce were not considered.

\section{Ecological Uncertainties}

There are uncertainties in the parameters used to estimate exposure for the ecological risk evaluation, but reported values for receptors' ingestion rates, size and home range, soil-toplant uptake factors, and soil-to-animal bioaccumulation factors are unlikely to be biased and should not severely or consistently over- or underestimate exposure. Exposure may be overestimated for some contaminants because the fraction available for absorption by animals may be overestimated. Extrapolation from studies involving laboratory doses to exposures at FDHTF is a major source of uncertainty in the estimate of risk to ecological receptors because the availability of the contaminant under test conditions may be greater than it is to receptors living in field conditions.

\section{Conclusions}

No human health primary or secondary preliminary COCs were identified under current land use assumptions. Secondary preliminary COCs were identified for the hypothetical industrial worker and on-unit resident. Due to the elimination of the preliminary human health COCs (arsenic, benzo(a)pyrene, beryllium, iron, and vanadium) through the uncertainty analysis 
process, no soil RGOs were developed for the FDHTF. No ecological RGOs were developed because there are no final ecological COCs.

\section{Site-Specific Considerations}

Site-specific considerations, based on the conclusions of the BRA and RFI/RI, which suggest no potential for significant risk include:

1) FDHTF originally contained soil that may have been contaminated with flammable liquids. Stained soils were removed in an earlier removal action.

2) The levels of surface soil contamination recognized during characterization are generally very low. The contaminants present are generally within the background levels of soil in the area.

3) The groundwater monitoring program indicates that there has not been significant impact from the waste materials in the pits.

4) The BRA did not determine any COCs after the uncertainty analysis and, therefore, no RGOs were prepared.

\section{Remedial Action Objectives}

Remedial action objectives specify unit-specific contaminants, media of concern, potential exposure pathways, and remediation goals. Remediation goals are developed based upon ARARs or risk-based concentrations. After the uncertainty analysis, the BRA determined that there are no unit-specific contaminants. Therefore, there are no remedial action objectives. No Action will be protective of human health and the environment.

\section{THE SELECTED REMEDY}

According to the EPA guidance document Guidance on Preparing Superfund Decision Documents (EPA, 1989), if there is no current or potential threat to human health or the environment and no action is warranted, the CERCLA 121 requirements are not triggered. 
This means that there is no need to evaluate other alternatives or the no action alternative against the nine criteria specified under CERCLA.

Under the No Action alternative, no treatment will be performed, no institutional controls or engineering controls will be implemented, and no cost is associated with implementing the alternative. According to CERCLA regulations, Section 121, if no action is the preferred alternative, then no applicable or relevant and appropriate requirements are associated with the alternative.

Based on the FDHTF RCRA RFI/RI/BRA Report, the FDHTF poses no significant risk to human health and the environment. Therefore, No Action has been selected as the remedial alternative which satisfies the CERCLA criteria. The No Action alternative is the final action for the FDHTF operable unit. This solution is meant to be permanent and effective in both the short and long term and is applicable to all media evaluated (soil, groundwater, etc.). The No Action Decision is the least cost option with no capital, operating, or monitoring costs, and is protective of human health and the environment.

This proposal is consistent with EPA guidance and is an effective use of risk management principles. The Statement of Basis/Proposed Plan provided for involvement with the community through a document review process and a public comment period.

The selected remedy is protective of human health and the environment and complies with Federal and State requirements that are legally applicable or relevant and appropriate to the remedial action. There is no irreversible and irretrievable loss of resources at the FDHTF.

\section{EXPLANATION OF SIGNIFICANT CHANGES}

The SB/PP and draft permit modification provided for involvement with the community through a document review process and a public comment period. There were no significa changes made to either the RCRA permit modification or the Record of Decision based on comments received during the public comment period. Comments that were received during the 45-day public comment period are addressed in Appendix A of this ROD and are available with the final RCRA permit. 


\section{RESPONSIVENESS SUMMARY}

No comments were received from the public during the public comment period. Therefore, a Responsiveness Summary is not included in Appendix A.

\section{REFERENCES}

DOE (U. S. Department of Energy), 1994. Public Involvement, A Plan for Savannah River Site. Savannah River Operations Office, Aiken South Carolina.

DOE, 1996. Savannah River Site Future Use Project Report. U. S. Department of Energy Savannah River Operations Office, Aiken, South Carolina, January, 1996.

EPA (U. S. Environmental Protection Agency), 1989. Guidance on Preparing Superfund Decision documents. Office of Solid Waste and Emergency Response - OSWER Directive 9355.3-02, Washington, DC, July 1989.

FFA, 1993. Federal Facility Agreement for the Savannah River Site, Administrative Docket No. 89-05-FF, (Effective Date: August 16, 1993).

WSRC, 1997a. RCRA Facility Investigation/ Remedial Investigation Report With Baseline Risk Assessment for the Fire Department Hose Training Facility (904- 113G) (U), WSRC-RP-96-863, Revision 1, Westinghouse Savannah River Company, Aiken, South Carolina (April, 1997).

WSRC, 1997b. Statement of Basis/Proposed Plan for the Fire Department Hose Training Facility (904- 113G) Operable Unit (U), WSRC-RP-97- 170, Revision 1, Westinghouse Savannah River Company, Aiken, South Carolina (October, 1997). 